\title{
Türkçe Eğitimi Doktora Tezlerine Bütünsel Bir Yaklaşım (1995-2020)
}

\author{
Doç. Dr. Beytullah Karagöz \\ Tokat Gaziosmanpaşa Üniversitesi, Eğitim Fakültesi \\ Türkçe ve Sosyal Bilimler Eğitimi Bölümü \\ beytullah.karagoz@gop.edu.tr
}

\author{
Doç. Dr. Izzet Şeref iD \\ Sivas Cumhuriyet Üniversitesi, Eğitim Fakültesi \\ Türkçe ve Sosyal Bilimler Eğitimi Bölümü \\ izzetseref@cumhuriyet.edu.tr
}

Öz

Bu çalışmada Türkiye'de 1995-2020 yılları arasında savunulan Türkçe Eğitimi doktora tezlerinin araştırma profilinin ortaya konması amaçlanmıştır. Araştırma, Yükseköğretim Kurulu Tez Merkezi verilerine dayalı olarak gerçekleştirilmiştir. Araştırmanın kapsamını Türkçe Eğitimi alanında tamamlanan toplam 248 doktora tezi oluşturmaktadır. Doktora tezleri yıllık tez üretimi, danışman unvanı, konu alanı, araştırma yöntem ve deseni, tezyayın oranı ölçütleri çerçevesinde ele alınmıştır. Çalışmanın verileri, içerik analizi tekniği ile çözümlenmiştir. Araştırma sonuçlarına göre, alanda en çok tez 2015 yılında üretilmiştir. Doktora çalışmaları, ağırlıklı olarak Prof. Dr. unvanlı akademisyenlerin danışmanlığında gerçekleştirilmiştir. Tezlerde desen olarak en çok karma araştırma desenleri tercih edilmiştir. Türkçe Eğitimi doktora tezlerinde, 2010 yılından sonra Yabancılara Türkçe Öğretimi konusunun yoğun olarak araştırıldığı tespit edilmiştir. Doktora tezlerinin yarısından fazlasının $(\% 53,22)$ yayına dönüştüğü belirlenmiştir.

Anahtar Kelimeler: Türkçe eğitimi, doktora tezleri, içerik analizi, bütünsel yaklaşım, yayin.

\section{A Holistic Approach to PhD Theses in Turkish Language Education (1995-2020)}

\section{Abstract}

This study aims to determine the research profiles of Ph.D. dissertations on Turkish language education submitted between 1995 and 2020 in Turkey. The study examines the main research themes and trends in Ph.D. dissertations with a comprehensive approach. The study is carried out based on the data of the Higher Education Council Thesis Center and analyzes 248 dissertations on Turkish language education. The dissertations are analyzed according to the criteria such as annual thesis production, keywords, subject area, the title of advisor, research method and design, data collection tools, data analysis method, sample selection method, and thesis-publication ratio. The data in the study are analyzed by content analysis to reveal the bibliographic, thematic, and methodological dimensions of the dissertations in detail. According to the results of the study, 2015 is the year that the most dissertations on this subject were produced. The Ph.D. dissertations are mainly submitted under the supervision of professor doctors. Mixed research designs are the most preferred design in dissertations. Since 2010, teaching Turkish to foreigners has attracted great interest in doctoral dissertations. It is clear that more than half of the dissertations $(53.22 \%)$ have 
been published. The Journal of Mother Tongue Education is the most preferred media organ for publication in dissertations that have turned into journal articles.

Keywords: Turkish Language education, Ph.D. dissertations, content analysis, holistic approach, publication. 


\section{GİRIŞ}

Disiplinlerin gelişmesinde anahtar rol üstlenen bilimsel çalışmalardan biri de doktora tezleridir. Doktora tezleri, kariyer başlangıcındaki araştırmacılar tarafından tek yazarlı olarak üretilençok önemli akademik araştırmalardır (Hall \& Burns, 2009; Evans ve diğerleri, 2018; Kousha \& Thelwall, 2019). Doktora eğitimi süreci; danışman seçimi, ders aşaması, doktora yeterlilik sınavı, tez önerisi, tez izleme komitesi toplantıları, tez savunma sınavı ve tez teslimi gibi aşamalardan oluşur. Bu sürecin sonunda doktor adaylarının, bilimsel yöntemi bağımsız şekilde uygulama becerisi kazanmaları, sağlam bir araştırma kültürü edinmeleri ve akademik bilgi üretme olgunluğuna ulaşmaları amaçlanır (Kushkowski ve diğerleri, 2003; Ogunyemi ve diğerleri, 2005; Kumar \& Stracke, 2007; Gao, Yu \& Luo, 2009; Soler-Monreal, Carbonell-Olivares \& Gil-Salom, 2011; Stubb, Pyhältö, \& Lonka, 2012). Dolayısıyla doktora tezi, akademik eğitim sürecinin temel ürünlerinden biri olarak kabul edilmektedir. Zira doktora tezleri aracılığıyla akademik alanyazında bilimsel bilgi alışverişine ilişkin önemli bilgiler elde edilebilmektedir. Özellikle bilim alanlarındaki mevcut durum ve gelişmeleri takip etmeyi sağlaması, alanın entelektüel yapısına ilişkin veriler sunması, kariyer başlangıcındaki genç araştırmacıların bilgi ihtiyacına yanıt vermesi, bilim alanlarının gelişimini ortaya koyması ve bilimsel bilgi üretimine sürdürülebilirlik kazandırması yönleri ile dikkate alınması gerekmektedir (Kuruppu \& Moore, 2008, Serenko ve diğerleri, 2010; Fernández-Cano, Torralbo \& Vallejo, 2012; Kot \& Hendel, 2012; Larivière, 2012; McCallin \& Nayar, 2012; Jones, 2013; Gould, 2016; Bangani, 2018). Bu bağlamda doktora tezleri bilim ekosisteminin önemli parçalarından birini oluşturmaktadır. Aynı zamanda, üniversitelerdeki lisansüstü eğitim öğretim etkinliklerinin de temel çıtıları olması nedeniyle akademik kadroların oluşumunda belirleyici bir rolü bulunmaktadır (Larivière, Zuccala \& Archambault, 2008; Lee, 2008; Trafford \& Leshem, 2008; Andersen \& Hammarfelt, 2011; Overall, Deane \& Peterson, 2011; Finlay ve diğerleri, 2012; Echeverria, Stuart \& Blanke, 2015; Geuna, 2015). Bu özellikleri nedeniyle bir bilim alanının gelişme ve ilerleme potansiyelini saptamak için alanda tamamlanan doktora tezlerini sistematik ve kapsayıcı bir biçimde boylamsal olarak farklı açlardan incelemek son derece önemli görülmektedir.

1989 yılında ilk Türkçe Eğitimi Bölümünün Gazi Üniversitesi çatısı altında “Türkçenin Eğitimi ve Öğretimi" adıyla kurulması ve eğitime başlamasından beri, Türkçe Eğitimi akademik alanı hızlı bir gelişim süreci içerisine girmiştir. 1992 yılında "Türkçe Öğretmenliği Ana Bilim Dalı" ilk öğrencilerini eğitim öğretime kabul etmiştir (Güzel, 2003a). Dört yıllık mesleki eğitim öğretim verilen bölümde Yüksek Öğretim Kurulu (YÖK) tarafından Eğitim Fakültelerinin yeniden yapılandırılması kapsamında 1998-1999 öğretim yılında değişikliğe gidilerek Türk Dili ve Edebiyatı Eğitimi Bölümü, Orta Öğretim Sosyal Alanlar Eğitimi Bölümüne Ana Bilim Dalı olarak kaydırılmış (Güzel, 2003b); 2016-2017 akademik yılında da Türkçe ve Sosyal Bilimler Eğitimi Bölümünde Türkçe Eğitimi Ana Bilim Dalı olarak yapılandırılmıştır.

Türkçe Eğitimi Ana Bilim Dalı, Eğitim Bilimleri temel alanının alt alanlarından biri olarak öğretmen yetiştirme alanında yer almaktadır. Bu kapsamda öğretmen adaylarının mesleki bilgilerini artırmayı, genel kültür düzeylerini yükseltmeyi ve öğretmenlik becerisi kazandırmayı temel amaç edinmiştir. Bunun yanı sıra 90’lı yılların sonuna gelindiğinde ortaokul Türkçe öğretmeni yetiştirme amacı yanına akademik donanım açısından yetkin bilim insanları yetiştirme amacı eklenmiştir. Bu genel duruma paralel olarak, alanda 2000'li yıllar boyunca bir araştırma altyapısı kurulmaya çalışılmış, alanyazın oluşturan 
üniversitelerde çeşitli adlar altında ana bilim dalları kurulmuş ve geliştirilmiştir. Doktora tez sayısının nicelik açısından henüz az olduğu bu dönemde, Türkçe Eğitimi alanının ilk çalışmaları yapılarak alanın bilimsel gelişimi yolunda ilk adımlar atılmıştır. 2005'te ise, çok farklı üniversitelerde Türkçe Öğretmenliği lisans programı açılmış; ayrıca yüksek lisans ve doktora düzeyinde de eğitime başlanmıştır. Dolayısıyla lisansüstü tez üretimi hız kazanmıştır. Bu dönemin alan açısından en büyük ortak özelliği ilk bölümlerin köklü araştırma kurumları olan Atatürk Üniversitesi, Gazi Üniversitesi, Ankara Üniversitesi, Dokuz Eylül Üniversitesi, Çanakkale Onsekiz Mart Üniversitesi gibi üniversitelerde açılması nedeniyle bu üniversitelerin alan üzerindeki etkisinin son derece belirleyici olduğudur. Bu kurumlar, alanın hem insan kaynağını yetiştirmeye çalışmakta hem de alandaki bilgi üretimi büyük ölçüde bu üniversitelerdeki lisansüstü eğitimlere bağlı olarak gerçekleşmektedir. Bugün gelinen noktada ise alanın ontolojik temelleri atılmış (Börekçi, 2015), lisans ve lisansüstü düzeyde kurumsallaşma aşaması tamamlanmış olup Türkçe Eğitimi giderek daha fazla önem kazanan bir alan olmuştur. Son yıllarda Türkçe Eğitimi bilim alanında tamamlanan lisans sonrası çalışmaların belirgin bir ivme kazandığı görülmektedir (YÖK, 2020; n=1691). Buna göre Türkçe Eğitimi alanında tamamlanan doktora tezlerinin alanın müstakil bir bilim sahası olarak gelişiminde etkili bir akademik çıktı olduğu düşünülmektedir. Bu yanıyla, bilim alanındaki gelişmelerin temelini oluşturmaya önemli katkılar sağlayabilir. Dolayısıyla alanda doktora yapan araştırmacılardan alanyazına katkı sunan kaynak bilimsel metinler üretmeleri ve bilime katkı yapan araştırmalar ortaya koymaları beklenmektedir.

İlgili alanyazın incelendiğinde, Türkçe Eğitimi makalelerinin ve lisansüstü tezlerinin eğilimlerini belirlemeye yönelik araştırmalar olduğu görülmektedir (Akaydın \& Çeçen, 2015; Eyüp, 2020; Karagöz, \& Şeref, 2020). Benzer şekilde Türkçe Eğitimi alanında temel dil becerileri (Coşkun, Balcı \& Özçakmak, 2013; Tok ve Potur, 2015); Yabancılara Türkçe Öğretimi (Şeref \& Karagöz, 2020); çocuk edebiyatı (Yazıcı, 2013) konularında değerlendirme ve eğilim belirlemeye dönük içerik analizi araştırmaları yapıldığı anlaşılmaktadır. Alanyazında Türkçe Eğitimi alanındaki yönelimleri bilimsel toplantılar üzerinden inceleyen araştırmalar da bulunmaktadır (Bozkurt \& Uzun, 2015; Şeref \& Karagöz, 2019a). Söz konusu çalışmalarda araştırmacılar, Türkçe Eğitimi alanındaki bilimsel toplantılarda sunulan bildirilerin analizine dayanan meta-araştırma çalışmaları yaparak alanın araştırma özelliklerini sistematik olarak değerlendirmiştir. Böylelikle alana özgü akademik toplantıların kuram ve uygulama boyutlarında bilimsel gelişime katkısının önemi tartışılmış ve saptamalarda bulunulmuştur. Yapılan meta-araştırma çalışmaları, Türkçe Eğitimi alanındaki çalışmaların sıklıkla tanımlayıcı (durum belirleme) olduğunu, alana yeni bir anlayış ve yöntem getiren çalışma sayısının azlığını ortaya koymuştur.

Ayrıca Türkçe Eğitimi alanında tamamlanan yüksek lisans tezlerini çeşitli yönlerden ele alan çalışmalar da mevcuttur. Bu çalışmalarda Sevim ve İşcan (2012) tezlerde kullanılan anahtar kelimeleri inceleyerek anahtar kelime analizi yapmıştır. Büyükikiz (2014) ise içerik analizi yöntemini kullanarak Yabancılara Türkçe Öğretimi tezlerinin yöntemsel özelliklerini ve çıtılarını irdelemiştir. Yine alandaki yüksek lisans tezlerini ele alan bir çalışmada Kan ve Uzun (2016), alanda yüksek lisans düzeyindeki tezlerin Yöntem bölümlerinde izlenen dilbilimsel hareket ve adımları incelemişlerdir. Sevim ve Özdemir-Erem (2012) de yüksek lisans tezleriniakademik yazma ölçütleri bağlamında değerlendirmişlerdir. Boyacı ve Demirkol (2018)ise alanda tamamlanan doktora tezlerini betimsel olarak incelemişlerdir. Bununla birlikte bilindiği kadarıyla alanyazında çalışmanın yürütüldüğü tarih itibarı ile 
Türkiye'de tamamlanan Türkçe Eğitimi doktora tezlerinin yöntemsel ve yayın eğilimlerini boylamsal olarak inceleyen herhangi bir çalışma bulunmamaktadır. Alanyazındaki boşluk nedeni ile alandaki araştırmacıların bilgi ihtiyacına ilişkin kanıta dayalı bilgi kılavuzları geliştirme bağlamında mevcut araştırmaya belirgin şekilde ihtiyaç bulunmaktadır. Ayrıca Türkiye'de tamamlanan doktora tezlerinin etki ve görünürlük düzeyinin yükselmesi açısından yerleşik alanyazına, yöntem bilgisi ve indeksli bilimsel yayınlara ihtiyaç duyulduğu belirtilmektedir (Yurtsever Gülgöz, 1999; Yaman \& Atay, 2007; Sipahi ve diğerleri, 2012; Bayramlar ve diğerleri, 2015; Yüksel, İpekçi \& Tunçkıran, 2018). Bu bağlamda çalışma, Türkiye'de Türkçe Eğitimi alanında savunulan doktora tezlerinin araştırma belleğine ve entelektüel birikimine ışık tutması, araştırma tekniği altyapısının özelliklerini betimlemesi ve alanın bilimsel gelişiminde tezlerin etkisini ortaya koyması bakımından önem taşımaktadır. Böylelikle alandaki doktora tezlerine farklı parametreler üzerinden daha ayrıntılı bir bakış açısı sunmak, tezlerin akademik topluluğun bilgi alışverişi üzerindeki etkisini incelemek, nicel ve nitel analizini yaparak alandaki güncel ve öncelikli tartışma alanlarını saptamak (Broadus,1987) ve geçmişi, bugünü ve gelişimi ile ilgili çok yönlü değerlendirmede bulunmak mümkün olabilecektir. Diğer taraftan doktora tezlerinde çalışılan araştırma konularındaki benzerlik ve farklılıklar tespit edilerek alana ilişkin olgu temelli bir araştırma perspektifi çizilebilecektir. Böylelikle alanda çok çalışılmış ya da az çalışılmış konular belirlenerek tez çalışması yürütecek genç araştırmacılara rehberlik yapılacak, araştırma çıktılarının özgünlük ve nitelik kazanmasına katkı sağlanacaktır. Ayrıca araştırma, alanda çalışılmamış analiz birimlerine odaklanarak genelde Eğitim Bilimleri ve Öğretmen Yetiştirme, özelde Türkçe Eğitimi üzerine yapılacak içerik analizi ve bibliyometri araştırmalarına katkıda bulunacaktır. Zira alanda lisansüstü tezlere odaklanan içerik analizi ve bibliyometri araştırmalarının hiçbirinde tezlerin yayına dönüşme oranlarının incelenmediği anlaşılmıştır. Çalışmaya yön veren araştırma soruları şunlardır:

1. Türkçe Eğitimi alanında 1995-2020 yılları arasında savunulan doktora tezleri için,

a. Yıllara göre dağılım nasıldır?

b. Danışmanların unvan dağılımı nasıldır?

c. Araştırma temalarının dağılımı nasıldır?

d. Araştırma desenlerine göre dağılım nasıldır?

e. Yayına dönüşme durumu nasıldır?

\section{YÖNTEM}

\section{Araştırma Modeli}

Bu çalışma betimsel bir araştırmadır. Betimsel incelemelerde "Araştırmalarda durum nedir? Neredeyiz? Ne yapmak istiyoruz? Nereye, hangi yöne gitmeliyiz? Oraya nasıl gideriz? gibi sorulara, mevcut zaman kesiti içinde olduğu düşünülen verilere dayanılarak cevap bulunmak istenir" (Kaptan, 1998, s. 59). Çalışmada betimsel araştırma perspektifi ile 1995-2020 döneminde tamamlanan doktora tezleri üzerinden Türkçe Eğitimi alanındaki bilimsel üretim kapsamlı bir anlayışla incelenmeye çalışılmıştır.

\section{Verilerin Toplanması}

$\mathrm{Bu}$ çalışmada kullanılan analiz kategorileri, daha önce alanyazında uygulanan çalışmalara dayanmaktadır (Veletsianos \& Shepherdson, 2016; Zainuddin\& Halili, 2016). Veri toplama aracı olarak yararlanılan bu kategoriler, Web of Science (WoS) atıf dizininde 
listelenen dergilerdeki araştırmalarda kullanılmış olması nedeniyle benimsenmiştir. Çalışmanın amacına uygun olarak gerekli görülen durumlarda benzer ölçütler altında standart değerlendirme yapabilmek için analiz birimleri üzerinde gerekli düzenlemeler yapılmıştır.

Çalışmada verilerin toplanması ve analizi aşamasında PRISMA yönergesinde belirtilen yaklaşım izlenmiştir. PRISMA, araştırmalarda yazarların bilimsel yol haritasını belgelemelerine yardımcı olarak incelemelerin sistematik biçimde yürütülmesini sağlar (Moher, Liberati, Tetzlaff, Altman ve PRISMA Group, 2009) (Şekil 1). Bu doğrultuda araştırmada izlenen adımlar aşağıda sıralanmıştır:

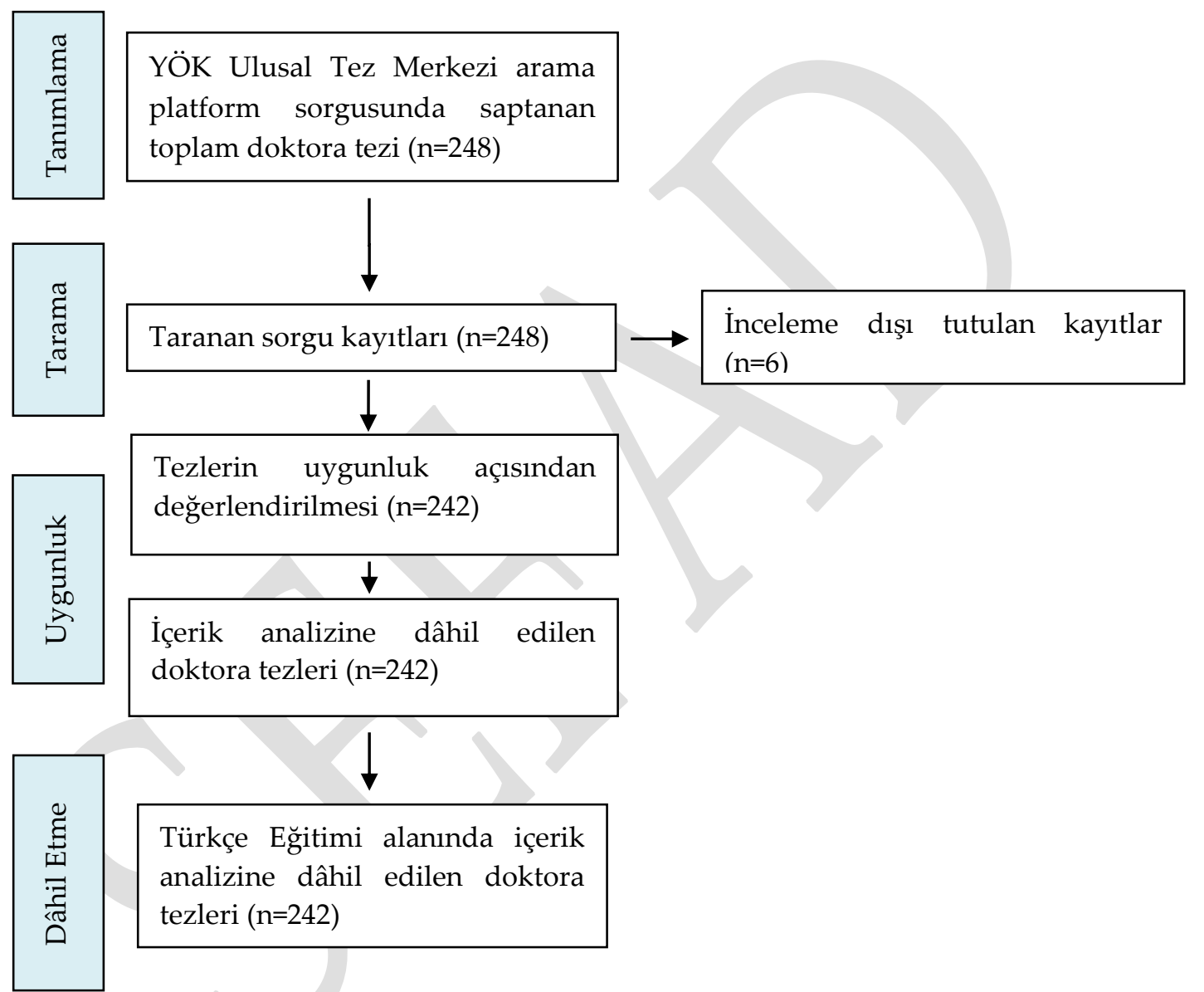

Şekil 1. Araştırma aşamalarına ilişkin akış diyagramı

Çalışmanın verileri, iki aşamalı bir veri toplama stratejisi ile elde edilmiştir. Birinci aşamada doktora tezleri için arama yapılmıştır. Bu kapsamda Yükseköğretim Kurulu Başkanlığı Ulusal Tez Merkezi arama platformu veri kaynağı olarak kullanılmıştır. Çalışmada ilk tarama 10 Kasım 2020 tarihinde yapılmıştır. Bu doğrultuda Ulusal Tez Merkezi "Detaylı Tarama" bölümünün altında yer alan Ana Bilim Dalı sekmesinden "Türkçe Eğitimi Ana Bilim Dalı", "Türkçenin Eğitimi ve Öğretimi Ana Bilim Dalı", "Türkçe Öğretmenliği Ana Bilim Dalı" ve "Türkçe Ana Bilim Dalı"; tez türü sekmesinden "doktora" seçilmiştir. Ana bilim dalı özelinde yıl aralığı sekmesinden ilgili tarihler seçilmiştir. Yapılan tarama sorgusunda toplam 248 kayıt elde edilmiştir. Çalışmada 1995-2020 döneminde tamamlanan tezlerin tümü inceleme kapsamına alınmıştır. Araştırmada açık erişime izin verilen ve niteleme bilgileri tez yazım standartlarına uygun olan tezler incelenmiştir. Tam 
metin erişim izni olmayan, tez kayıt bilgilerinde standart bulunmayan ve tez veri girişleri hatalı olan tezler kapsam dışı tutulmuştur.

İkinci aşamada doktora tezlerinin yayına dönüşme oranları sorgulanmıştır. ERIC (https://eric.ed.gov/), Google Akademik, Web of Science (http://apps.webofknowledge.com/) ve ULAKBIM TR Dizin (https://trdizin.gov.tr/) veri tabanlarında 14 Kasım 2020'de başlanan sorgu taraması 20 Aralık 2020'de tamamlanmıştır. Bu sorgulamada tez başlıkları iki farklı dilde (Türkçe ya da İngilizce) arama platformuna yazılarak arama sorgusuna başlanmıştır. Çalışmanın bulunamadığı durumlarda, yazarın ve/veya tez danışmanının adı platforma girilerek sorguya devam edilmiştir. Tez çalışmasının bir bölümünün yayına dönüştürülebileceği düşüncesi ile tez yazarının varsa (https://akademik.yok.gov.tr/AkademikArama/) arama motorundaki kişisel sayfası, Google Akademik profili, varsa kişisel blog, akademik sosyal medya hesapları (Researchgate, Academia vb.) gözden geçirilmiştir. Bu taramalara karşıllk sonuç yine olumsuz ise tezlerde belirtilen iletişim adreslerinden tez yazarlarına mail, telefon yolu ile ulaşılarak bilgi edinilmiştir. Araştırma kapsamı dışında kalan diğer indekslerde veya herhangi bir dizinde yer almayan dergilerde yayımlanan tezden üretilmiş yayınlar uluslararası herhangi bir dizinde taranıor ise, "uluslararası makale", ulusal isimli bir dergi ise "ulusal makale" başlı̆̆ altında değerlendirilmiştir.

WoS: SSCI (Social Science Citation Index) ve ESCI (Emerging Sources Citation Index), Scopus, ERIC (Education Resources Information Center), uluslararası diğer dizinlerde (MLA, Index Copernicus vb.) listelenen dergilerde yayımlanan makaleler "uluslararası"; ULAKBİM TR Dizin ile ulusal hakemli dergilerde yayımlanan makaler ise "ulusal" olarak ele alınmıştır. Kitaplara ait dizin bilgileri de bu doğrultuda değerlendirilmiştir. Dergilerin güncel etki faktörü değerlerine ise (https://atif.sobiad.com/index.jsp?modul=impact-faktoru) bağlantı adresinden erişilmiştir.

\section{Veri Analizi}

Araştırma sürecinde ulaşılan veriler içerik analizi tekniği ile çözümlenmiştir. Yazılı metinlerin, eserlerin, resimlerin ve kayıtların içeriğini inceleyen bu yöntem(Creswell, 2016); metin, konuşma, görüntü veya video yoluyla iletişim içeriğindeki eğilimleri belirlemek, sınıflandırmak ve kategorilere ayırmak için kullanılan sistematik bir analizdir (Powell \& Connaway, 2004; Krippendorff, 2012). Ayrıca içerik analizi ile yayın kümeleri değerlendirebilmekte; kategori geliştirme, sıklık hesaplama ve yorumlama aşamaları dâhil olmak üzere makalelerin analiz ve yorumlanma süreci dikkatlice tamamlanabilmektedir (Falkingham\&Reeves, 1998). Türkçe Eğitimi doktora tezlerindeki örüntü, ilgili alanyazına dayalı olarak araştırmacılar tarafından önceden belirlenen analiz birimleri dikkate alınarak kodlanmıştır.

Tematik analizde kodlama ile ilgili farklılıkları en aza indirmek amacıyla kodlayıcılar arası tutarlılık belirlenmeye çalışılmıştır. Bu kapsamda toplam tez sayısının \%20'si olan 48 tez seçkisiz olarak belirlenmiş ve araştırmacılara dağıtılmıştır. Araştırmacılar birbirlerinden bağımsız biçimde Microsoft Excel programı aracılığıyla açık kodlamalar yapmışlardır. Daha sonra oluşturulan kod tabloları karşılaştırılmak üzere bir araya getirilmiştir. Farklı görüşlerin olduğu noktalar tartışılmış, uzlaşılmış ve bu doğrultuda kodlar güncellenmiştir. Böylelikle bağımsız olarak gerçekleştirilen ilk analizlerde Miles ve Huberman (1994) formülüne göre \%90 kodlayıcılar arası uyuma ulaşılmıştır. 
Araştırmada tezlerden çıkarılan makalelerin yayımlanması için tercih edilen dergiler ile dergilere ait etki faktörleri arasındaki ilişkiyi analiz etmek amacıyla SPSS 22.0 paket programından (IBM Corp., Armonk, NY, ABD) yararlanılmıştır. Bu bağlamda Pearson Momentler Çarpım Korelasyon Katsayısı'nın parametrik olmayan versiyonu Spearman Sıra Farkları Korelasyon Katsayısı kullanılmıştır. İstatistiksel anlamlılık için $p<, 05$ değeri kabul edilmiştir.

\section{BULGULAR}

Çalışmanın kapsamı doğrultusunda ulaşılan bulgular belirlenen değişkenlere göre sıralı olarak aşağıda sunulan başlıklar altında verilmiştir.

\section{Yıllara Göre Dağılım}

Tezlerin yıllara göre dağılımları Grafik 1'de gösterilmiştir.

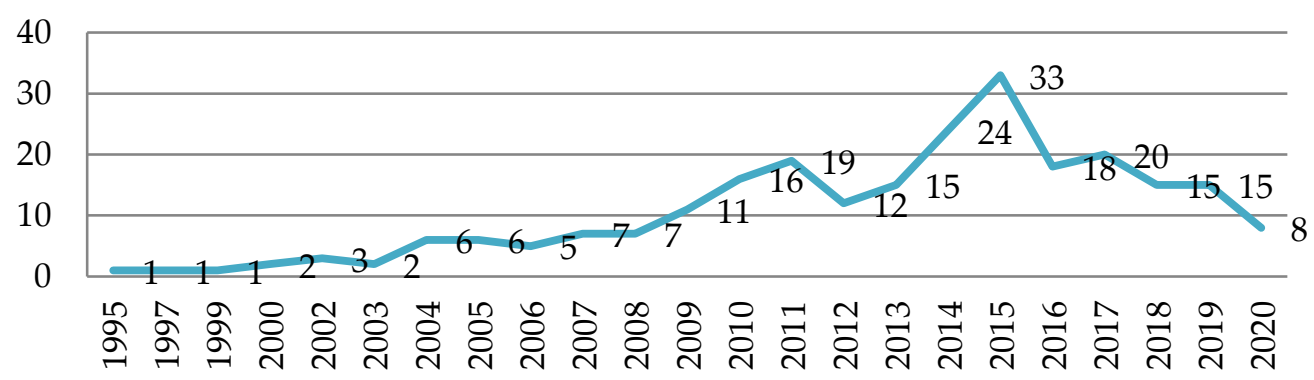

Grafik 1. Doktora tezlerinin yıllara göre dağılımı

Alanın mevcut durumunu analiz etmek ve geleceğe ilişkin olarak yapılması gerekenler hakkında çıkarımda bulunabilmek amacı ile ilk olarak 1995-2020 yılları arasında tamamlanan tez sayıları incelenmiştir. Böylelikle bilim alanının genel görünümü ve nerede olduğu belirlenmek istenmiştir. Tezlerin tamamlanma yıllarına göre analizi ile başlangıcından bugüne alandaki bilimsel etkinliğe yönelik kapsamlı bir bakış sağlamak mümkün olacaktır. Buna göre Türkçe Öğretmenliği bölümlerinin yeni kurulması ve üniversitelerde Türkçe Eğitimi lisansüstü programlarının az sayıda olmasına bağlı olarak ilk yıllarda üretilen tezler düşük düzeyde yatay bir seyir izlemiştir. İzleyen 5 yıl (2000-2005) tablosunda çok az bir değişiklik meydana gelmiştir. 2005 sonrasında ise doktora tezi üretiminde bir ivme yakalandığı görülmektedir. Her yıl artan bir oranda tez üretimi gerçekleştirilmiştir. Ancak, 2012 yılında bir yavaşlama olduğu görülmüştür. Önümüzdeki evrede 2015 yılı zirve noktası olmuş ve sonrasında belirli düzeyde tez üretilmeye devam edilmiştir. Bu artışın temel nedeni birçok üniversitede Türkçe Eğitimi doktora programının açılması ve çok sayıda genç araştırmacının alanda akademik çalışma yapmaya ilgi göstermesidir. Bu dönemle birlikte Türkçe Eğitimi alanı bilimsel bir araştırma alanı olarak kurumsallaşma yönünde etkinlik kazanmıştır. 2016 ve sonrası dönemde tamamlanan tezlerin oranı nispeten eşittir ve toplam tez sayısının \%27.41'lik bölümüne karş1lık gelmektedir. Bu bakımdan toplam tezlerin üçte birinin son dört yılda üretildiğini söylemek mümkündür.

\section{Danışman Unvanları}

Bu bölümde dönemler hâlinde tez yöneticilerinin unvan dağılımları sunulmuştur. 
Prof. Dr. $\quad$ Doç. Dr. $\quad$ Dr. Öğr. Üyesi/Yrd. Doç. Dr.

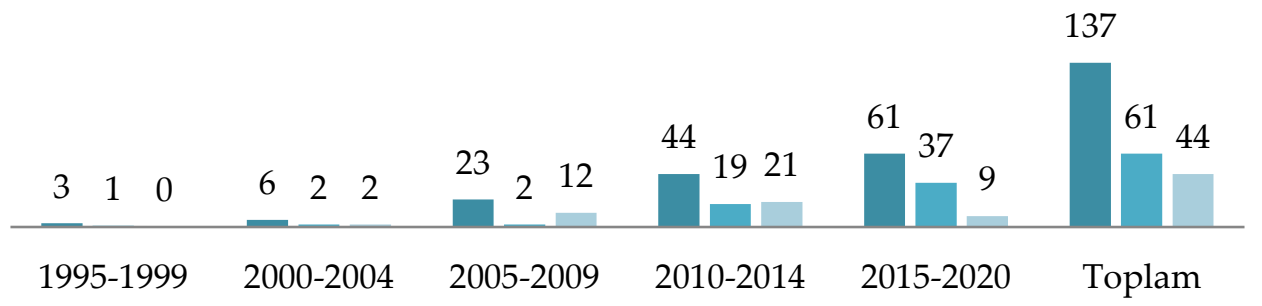

Grafik 2.Doktora tez danışmanlarının dönemlere göre unvan dağılımı

Grafik 2'de tez danışmanlarının dönemlere göre unvan dağılımı verilmiştir.Tezlerdeki danışman unvanlarının dağılımlarına bakıldığında tüm dönemlerde Prof. Dr. unvanlı araştırmacıların daha çok tez yönettikleri anlaşılmaktadır. Prof. Dr. unvanlı araştırmacıların 137, Doç. Dr. unvanlı araştırmacıların 61, Dr. Öğr. Üyesi/Yrd. Doç. Dr. unvanlı araştırmacıların 44 teze danışmanlık yaptıkları görülmektedir. Buna göre 2005-2009 döneminde üretilen 37 tezin 12'sini Dr. Öğr. Üyesi/Yrd. Doç. Dr. unvanlı araştırmacıların, 2 'sini ise Doç. Dr. unvanlı araştırmacıların yönettiği bulgulanmaktadır. Bu veri, anılan dönemde Türkçe Eğitimi alanında Doç. Dr. unvanlı araştırmacıların niceliksel azlığı ve henüz alanın ilk doktorlarının bilimsel faaliyetlerini Dr. Öğr. Üyesi/Yrd. Doç. Dr. unvanı ile gerçekleştirmiş olmaları şeklinde açıklanabilir. Bu doğrultuda gözlemlenen bir başka bulguya göre anılan dönemde tezlerin daha çok Filoloji temel alanında uzman olan Prof. Dr. ve Dr. Öğr. Üyesi/Yrd. Doç. Dr. unvanlı araştırmacıların danışmanlığında hazırlanmıştır. 2010 yılı itibarı ile Türkçe Eğitimi alanında Doç. Dr. unvanlı araştırmacı sayısındaki artış, tez danışmanlarındaki unvan dağılımlarını da etkilemiştir.

\section{Araştırma Temaları}

Bu bölümde araştırma temalarının dağılımına yönelik bulgular yansıtılmıştır.

\begin{tabular}{|c|c|c|c|c|c|}
\hline & & & & & \\
\hline & & & & & \\
\hline & & & & & \\
\hline & & & & & \\
\hline & & & & & \\
\hline & & & & & \\
\hline & & & & & \\
\hline & & & & & \\
\hline & & & & & \\
\hline & & & r & & \\
\hline & 1995-1999 & $2000-2004$ & 2005-2009 & $2010-2014$ & $2015-2020$ \\
\hline Değerler Eğitimi & 0 & 0 & 0 & 7 & 8 \\
\hline Çocuk Edebiyatı & 0 & 0 & 0 & 7 & 7 \\
\hline Konuşma Eğitimi & 0 & 0 & 0 & 5 & 4 \\
\hline Yazma Eğitimi & 0 & 0 & 0 & 12 & 16 \\
\hline Dinleme Eğitimi & 0 & 0 & 0 & 5 & 6 \\
\hline Okuma Eğitimi & 0 & 2 & 4 & 10 & 18 \\
\hline $\begin{array}{c}\text { Yabancılara Türkçe } \\
\text { Öğretimi }\end{array}$ & 2 & 0 & 0 & 12 & 26 \\
\hline
\end{tabular}

Grafik 3. Doktora tezlerinin araştırma temaları 
Grafik 3'te doktora tezlerinin araştırma temalarıverilmiştir. İlk dönemlerde üretilen çoğu tezde anahtar kelimelere yer verilmediği görülmüştür. Anahtar kelimelerin olmadığı durumlarda, tezin başlı̆g 1 ve konusundan hareketle anahtar kelimeler belirlenmeye çalışılmıştır. Araştırmacıların süreçte karşılaştıkları bir diğer sorun, anahtar kelimelerin hatalı belirlenmesidir. Bazı tezlerdeki anahtar kelimelerin konu ile ilgisi kurulamamış, bazı anahtar kelimelerin ise çok genel ya da çok özel olduğu gözlenmiştir. Bu anlamda özellikle 1995-2005 döneminde araştırmacıların akademik yazma becerileri açısından sorunlar yaşadıkları ifade edilebilir. Bu durum, o yıllardaki tezlerin Türkçe Eğitimi akademik alanının ilk bilimsel çıktıları olması nedeniyle doğal görülebilir. Ancak anahtar kelimelerin, bilimsel çalışmaları tanımlayan etiket kavramlar olduğu da göz ardı edilmemelidir.

Dil eğitimi alanı olarak Türkçe Eğitimi akademik alanının temel dil becerileri (okuma, dinleme, konuşma, yazma), Yabancılara Türkçe Öğretimi, çocuk edebiyatı gibi ana çalışma alanları vardır. Alanda araştırma yapan bilim adamları genellikle bu alt alanlara yönelirler. Bugünden bakıldığında çeşitli yayın türlerinde söz konusu alanlarla ilgili çokça çalışmaya rastlanmakta ve yayınların bu alanlarda yoğunlaştığı izlenmektedir. Doktora tezlerinde 2010 yılına kadar farklı türde konu alanlarının ele alındığı görülmektedir. Bu bulgu aslında Türkçe Eğitimi alanında doktora tezleri özelinde belirgin gelişimin 2010 yılından sonra yaşandığını ortaya koymaktadır. Nitekim bu yılla birlikte tez sayısındaki niceliksel artış da bu veriyi desteklemektedir. Diğer bir deyişle tez sayısındaki artış, tezlerdeki tematik gelişime katkı sunmuştur. Bu dönemden sonraki süreçte tezlerdeki konu yelpazesi genişlemiş, bununla birlikte alt konu alanlarında güncel bağımsız değişkenlerin etkisini irdeleyen yeni çalışmalar yapılmıştır.

Doktora tezleri dönemsel değerlendirmeye tabi tutulduğunda ilk beş yıllık dönemde üç tezin olduğu, bu tezlerden ikisinin Türk soylulara Türkiye Türkçesi öğretimi ile ilgili olduğu görülmektedir. Bu konunun anılan dönemlerde ilgi görmesi, başta Türk Cumhuriyetleri olmak üzere, Türkiye' nin diğer milletlerle iş birliğini geliştirme politikasının Türkçe Eğitimi alanına yansıması ile ilişkili olabilir. Nitekim Türk İşbirliği ve Koordinasyon Ajansı Başkanlığı (TIKKA) gibi kurumların Türk soylulara Türkçe öğretimi konusunu desteklemesi alanda ciddi düzeyde bilimsel bilgi üretimine katkı sağlamıştır.

2000-2004 yıllarında daha çok okuma alanı ile ilgili kavramların irdelendiği; bunun dışında öğretmen yeterlilikleri, şiir, değerler eğitimi gibi çeşitli alanlara yönelik tezlerin üretildiği anlaşılmaktadır. Söz konusu beş yıllık dönemde, araştırmacıların Türkçe Eğitimi akademik alanı için güncel ve orijinal kabul edilebilecek temalara yönelmeye başladıkları, aynı zamanda Filoloji temel alanının öğretilerinden büyük ölçüde etkilendikleri dikkat çekmiştir. Çünkü özellikle okuma ile ilgili araştırmaların, okuma becerisinin öğretiminden daha çok metin inceleme ve değerlendirmeye yönelik olduğu saptanmıştır. Bu durum alanın 2000-2004 döneminde araştırma prensipleri bakımından Filoloji alanından beslendiğini göstermektedir.

Sonraki beş yıllık dönemde doktora tezleri özelinde alanın gelişiminin hızlandığı belirtilebilir. Anahtar kelimelerin dağılımına bakıldığında sözcük öğretimi, söz varlığı, okuma becerisi, dil bilgisi öğretimi, öğretim programı ve ders kitabı, ölçme ve değerlendirme gibi kavramlar dikkat çekmektedir. Diğer yandan çocuk edebiyatı ile ilgili kavramlara da ilk olarak bu dönemde rastlanmaktadır. Özetle bu dönem doktor adaylarının, alanda daha önce tartışılmayan konulara ilgi duydukları, Türkçe Eğitimi alanının Filoloji 
disiplininin etki alanından uzaklaşıp alana özgü çalışma prensiplerini ve araştırma temalarını oluşturmaya başladıkları dönem olarak kabul edilebilir.

2010-2014 döneminde okuma becerisine olan ilginin artarak devam ettiği tespit edilmiştir. Bu dönemde yazma becerisi, konuşma becerisi, dinleme becerisi, Yabancilara Türkçe Öğretimi alt alanlarına ilişkin kavramlar Türkçe Eğitimi alanında tematik zenginliğin oluştuğunu göstermektedir. Bir diğer dikkat çekici durum ise araştırmacıların argümantasyona dayalı dil eğitimi, aktif öğrenme, çoklu zekâ, iletişimsel yaklaşım gibi güncel ve popüler öğretim/öğrenme kuramlarına çalışmalarında yer vermeye başlamalarıdır. Bu çalışmalar, alana konu bağlamında yön çizerken, eğitim öğretimi hedefleyen içeriklerin oluşmasına da olanak tanımıştır. Ayrıca 2009 yılında faaliyetlerine başlayan Yunus Emre Enstitüsünün Türkçenin eğitimi ve öğretimi konusundaki bilimsel çalışmaları destekleme misyonunu açıklaması, bu dönemde Yabancılara Türkçe Öğretimine duyulan ilgiyi artırmıştır. Türkçe Eğitimi doktora tezlerinde değerler eğitimi konusu da bu dönemde araştırmacıların dikkatini çeken alt alanlardandır. Bu bağlamda doktor adayları romanlar ve çocuk kitapları örnekleminde değer/eğitsel unsur/eğitsel ileti odaklı incelemelere yönelmişlerdir. Bu bulgunun, Millî Eğitim Bakanlığının karakter ve değer eğitimi konusuna önemle yer vermesi ile ilişkili olduğu düşünülmektedir. Ayrıca bu konuda Türkçe Eğitimi alanının araştırma felsefesine yakın olmayan alandaki Filoloji etiketli araştırmacıların da etkili olduğu söylenebilir. Çünkü Filoloji araştırmacıları, danışmanı oldukları tezlerde çocuk edebiyatı metinlerini değerler eğitimi bakımından incelettirerek tezlerin araştırma yönünü uzmanlık alanlarıyla örtüştürmeye çalışmış olabilirler.

Türkçe Eğitimi akademik alanında 2015-2020 döneminde okuma ve yazma becerileri önceki dönemlere göre daha yoğun olarak irdelenmiştir. Ayrıca araştırmalarda ilgili beceri alanlarında, 21. yüzyıl okuryazarlığı, görsel okuryazarlık, akademik yazma, üstbilişsel okuma ve yazma stratejileri gibi yenilikçi kavramlar üzerinde durulmuş olması, doktor adaylarının güncel konu alanlarına yöneldiklerini ortaya koymaktadır. Bu dönemde en belirgin tema, Yabancılara Türkçe Öğretimi alt alanıdır. Belirtilen dönemde üretilen 26 tezin konusu Yabancılara Türkçe Öğretimidir. Bu veri, son beş yıllık süreçte yaklaşık olarak dört tezden birinde Yabancılara Türkçe Öğretiminin amaçlandığı anlamına gelmektedir. Tez içerikleri düşünüldüğünde araştırmacıların bu yoğun ilgisinin sebebinin, son yıllarda Türkiye'ye lisans ve lisansüstü eğitim görmek amacıyla gelen yabancı öğrencilerin sayısındaki ciddi artış sonucunda oluşan Yabancılara Türkçe Öğretimi uzman ihtiyacı olduğu belirtilebilir. Söz konusu alana duyulan ilginin, Türkiye'ye Suriye, Irak, İran, Afganistan, Somali gibi ülkelerden gerçekleşen göç hareketliliği ile ilerleyen yıllarda daha da artacağını söylemek mümkündür. Yine bu dönemde dikkat çeken bir diğer konu alanı dil bilgisi öğretimidir. Konu ile ilgili tezlerde araştırmacıların, dil öğretimini dil bilimin verilerinden yararlanarak işledikleri; eleştirel söylem çözümlemesi, metindilbilim, göstergebilim temelli dil öğretim içerikleri tasarladıkları ve bu kuramların dil öğretim sürecine etkilerini sorguladıkları görülmüştür.

\section{Araştırma Desenleri}

Çalışmanın bu bölümünde tezlerin araştırma desenleri incelenmiş ve ulaşılan bulgular sunulmuştur.

SEFAD, 2021; (46): 43-68 


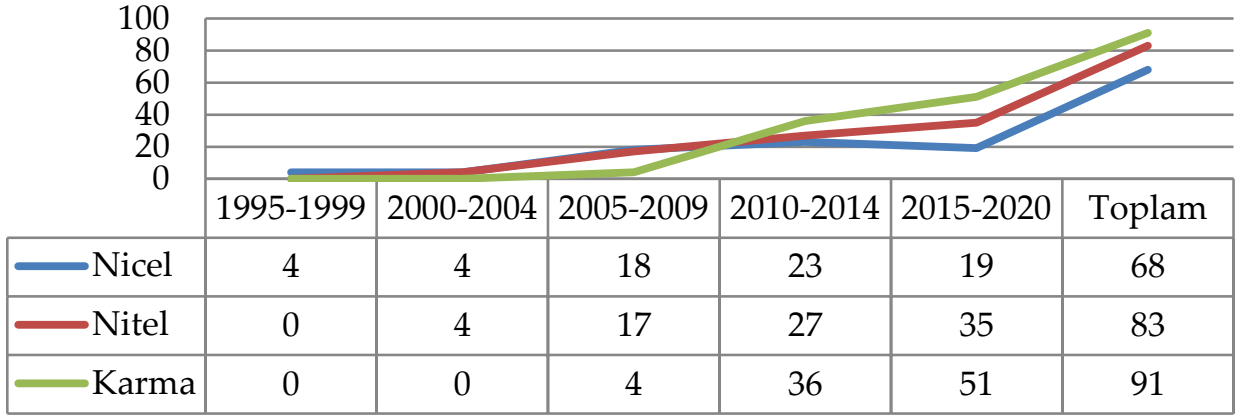

Grafik 4.Doktora tezlerinin araştırma desenleri ve dönemlere göre dağılımı

Grafik 4'te doktora tezlerinin araştırma desenleri ve dönemlere göre dağılımı verilmiştir. Tezlerin desenleri dönemsel olarak incelendiğinde ilk beş yıllık dönemde hazırlanan 4 tezin nicel tarama; ikinci beş yıllık dönemde 8 tezin $4^{\prime}$ ünün nicel, 4 'ünün nitel; üçüncü beş yıllık dönemde 18 tezin nicel, 17 tezin nitel, 4 tezin karma; dördüncü dönemde 23 tezin nicel, 27 tezin nitel, 36 tezin karma; beşinci dönemde 19 tezin nicel, 35 tezin nitel, 51 tezin karma araştırma desenleri ile tasarlandığı bulgulanmaktadır (Grafik 4). Genel olarak karma araştırma desenlerinin ilk olarak 2005-2009 döneminde kullanıldığı, 2010-2014 döneminde karma araştırma sayısında belirgin bir ivmelenmenin yaşandığı anlaşılmaktadır. Ayrıca nitel araştırma sayısında istikrarlı bir artış yaşanırken, nicel araştırmaların 2015-2020 döneminde bir önceki döneme göre daha az tercih edildiği görülmektedir. Tezlerde kullanılan alt araştırma desenleriyle ilgili bulgular ilerleyen bölümde sunulmuştur.

Tablo 1. Doktora tezlerindeki alt araştırma desenleri

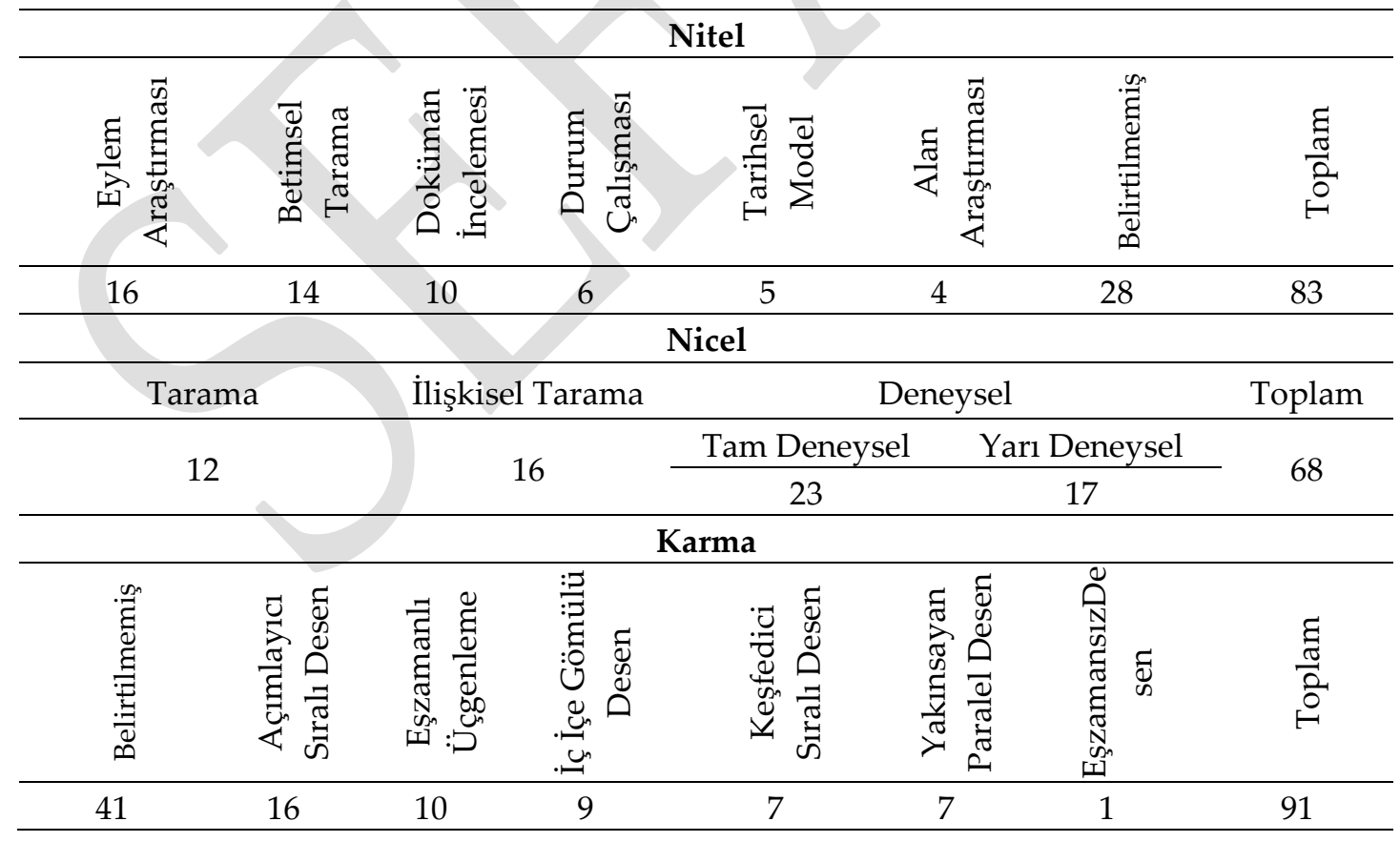

Tablo 1'de Doktora tezlerindeki alt araştırma desenleriverilmiştir. Nitel araştırma desenlerinden en çok kullanılan desen, eylem araştırması olmuştur. Bu çalışmalarda araştırmacılar, gözlemlenen bir sorunu; öğrenci, öğretmen, veli, okul yöneticileri gibi paydaşların katılımı ve süreci ilgilendiren dokümanların incelenmesi ile betimlemeyi ve çözüm önerileri ortaya koymayı amaçlamışlardır. Eylem araştırmasını betimsel tarama 
izlemiştir. Doktor adaylarının, doküman incelemesi (roman, hikâye, vb.) şeklinde planladıkları tezlerde genellikle betimsel tarama modelini kullandıkları saptanmıştır. Diğer yandan 28 tezde herhangi bir desen belirtilmediği, sadece çalışmanın nitel araştırma geleneğine uygun olarak yapılandırıldığı ifade edilmiştir.

Nicel tezlerin 28'i betimsel, 40' 1 ise deneyseldir. Betimsel tezlerin 12'si tarama, 16's1 ilişkisel tarama modelindedir. Deneysel tezlerin 23'ü tam deneysel, 17'si yarı deneyseldir. Bu verilerden hareketle nicel tezlerde desen çeşitliliğinin olmadığını, araştırmacıların çoğunlukla benzer modelleri tercih ettiklerini söylemek mümkündür.

Karma araştırma desenleri doğrultusunda hazırlanan tezlerde en çok açımlayıcı sıralı desen kullanılmıştır. 41 tezde ise herhangi bir desen belirtilmemiştir. Karma araştırmalarda desen seçimi, nicel ve nitel verilerin nasıl, hangi amaçla ve hangi oranda kullanıldığı ile ilgilidir. Araştırmacıların desen belirlerken bu noktalara dikkat etmeleri gerekmektedir. Ancak karma desenli tezlerin yaklaşık yarısında bu durumun göz önünde bulundurulmadığı belirlenmiştir.

\section{Yayın Sayısı, Yayın Türü ve Dizin}

Araştırmacılar tarafından yayına dönüştürülerek yayımlanan doktora tezlerinin yayın türü ve oranları aşağıda listelenmiştir.

Tablo 2. Doktora tezlerinin yayın sayısı, yayın türü ve dizine göre dağılımı

\begin{tabular}{|c|c|c|c|c|c|c|c|c|}
\hline 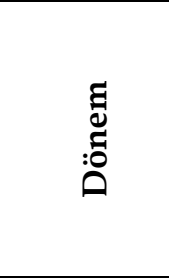 & 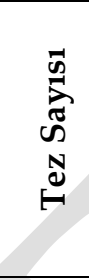 & 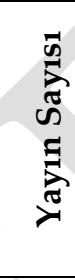 & 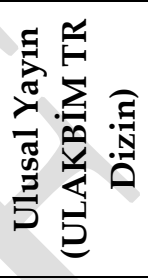 & 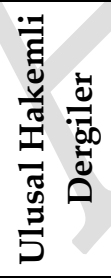 & 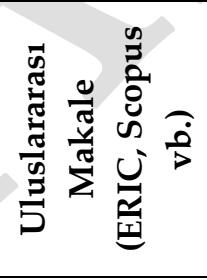 & 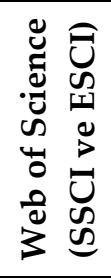 & 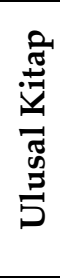 & 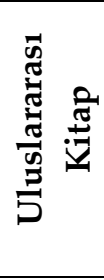 \\
\hline 1995-1999 & 3 & - & - & - & - & - & - & - \\
\hline $2000-2004$ & 13 & 4 & 3 & 1 & - & - & - & - \\
\hline 2005-2009 & 36 & 20 & 10 & 3 & 2 & - & 5 & - \\
\hline $2010-2014$ & 87 & 51 & 29 & 7 & 8 & - & 7 & - \\
\hline 2015-2020 & 109 & 57 & 31 & 3 & 15 & 7 & 1 & - \\
\hline Toplam & 248 & 132 & 73 & 14 & 25 & 7 & 3 & - \\
\hline
\end{tabular}

Tablo 2'de doktora tezlerinin yayın sayısı, yayın türü ve dizine göre dağılımıgösterilmiştir. Doktora eğitimi, uzun ve zorlu bir süreçtir. Bu sürecin sonunda ulaşılan bilgiler bilimsel iletişim açısından oldukça önemlidir. Bu nedenle tezlerin çok yönlü olarak incelenmesi, akademik ortamlarda paylaşılması ve bilim çevrelerinin bilimsel değerlendirmesine sunulması gerekli görülmektedir. Bu durumda akademik niteliği tez jürisi tarafından onaylanan tezler, bilimsel değeri yönünden bilim dünyasının denetimine açılmış olur. Bu doğrultuda tezlerin bilimsel dergilerde yayımlanması, tezlerin bilimsel kalitesi hakkında dönüt sağlarken, bilimsel bilginin hızla yayılmasına, yeni bilimsel araştırma sonuçlarının akademik dünya ile paylaşılmasına ortam hazırlar (Oliveira ve diğerleri, 2009; Dhaliwal, Singh \& Bhatia, 2010). Buna göre tezlerin hakemli dergilerde yayımlanma düzeyi, araştırmaların bilime yaptığı katkıya ve doktora eğitimi sürecinin bilimsel başarısına yönelik ipuçları sağlamaktadır (Lindahl, Colliander \& Danell, 2020). Buna karşılık yoğun bir emek ürünü olan tezlerin yayımlanmaması bilim dünyasının yapılan 
çalışmalardan haberdar olmasını engellemekte ve entelektüel bilgi alışverişini kısıtlayarak bilimsel ilerlemeye ket vurmaktadır (Demola ve diğerleri, 2009; Donegan, Kim \& Lee,2010).

Suber'in (2012, s. 106) de belirttiği gibi bilimsel kurumların yüksek standartlarını ortaya koyan tez ve tezlerin yayımlanarak paylaşılması, akademik kuruma prestij kazandırır ve alandaki diğer araştırmacılara fayda sağlar. Bu bakımdan tezlerin yayımlanması son derece önemlidir. Yayına dönüşmeyen tezler ise kaybedilmiş bilimsel bilgidir (Sprague ve diğerleri, 2003; Hernández-González, De Pano-Rodríguez \& Reverter-Masia, 2020). Araştırma kapsamında incelenen 1995-2020 arasındaki 25 yıllık dönemde alanda toplam 248 doktora tezi üretilmiş olup, araştırmada \%53,22'lik tez-yayın oranı saptanmıştır. Bu tezlerin 87 'si $(\% 35,08)$ ulusal dizinlerde; 32'si $(\% 12,9)$ ise uluslararası dizinlerinde yer alan dergilerde makale olarak yer almıştır. Doktora tezlerinin 7'si (\%2,8) bibliyometrik atıf veri tabanlarından olan Web of Science'ta yayımlanmıştır. 116 tez ise $(\% 46,7)$ herhangi bir belge formatında yayımlanmamıştır. Tablo 3'te yayına dönüştürülen tezlerin en sık yayımlandığ 1 hakem denetimli dergilere ilişkin bulgular sunulmaktadır.

Tablo 3.Tezlerin iki ve daha fazlasının yayımlandığı dergiler

\begin{tabular}{|c|c|c|c|}
\hline Derginin Adı & $\begin{array}{c}\text { Makale } \\
\text { Sayısı }\end{array}$ & Dizin & $\begin{array}{c}\text { Etki } \\
\text { Faktörü* }\end{array}$ \\
\hline Ana Dili Ĕ̆itimi Dergisi & 18 & TR Dizin & 0,470 \\
\hline $\begin{array}{l}\text { Mustafa Kemal Üniversitesi Sosyal } \\
\text { Bilimler Enstitüsü Dergisi }\end{array}$ & 13 & $\begin{array}{l}\text { Diğer endeksler (Index } \\
\text { Copernicus, İSAM) }\end{array}$ & 0,400 \\
\hline Turkish Studies & 10 & TR Dizin & 0,216 \\
\hline $\begin{array}{l}\text { Uluslararası Türkçe E } \\
\text { Eğitim (TEKE) Dergisi }\end{array}$ & 9 & TR Dizin & 0,405 \\
\hline $\begin{array}{l}\text { International Journal of Language } \\
\text { Academy }\end{array}$ & 5 & Diğer endeksler (MLA) & 0,126 \\
\hline $\begin{array}{l}\text { Erzincan Üniversitesi Eğitim Fakült } \\
\text { Dergisi }\end{array}$ & 4 & TR Dizin & 0,382 \\
\hline Ekev Akademi Dergisi & 3 & TR Dizin & - \\
\hline Türklük Bilimi Araştırmaları & 3 & TR Dizin & 0,073 \\
\hline Eğitim ve Bilim & 3 & SSCI & 0,882 \\
\hline $\begin{array}{l}\text { Bartın Üniversitesi Eğitim Fakültesi } \\
\text { Dergisi }\end{array}$ & 2 & TR Dizin & 0,579 \\
\hline Bayburt Eğitim Fakültesi Dergisi & 2 & TR Dizin & 0,716 \\
\hline $\begin{array}{l}\text { International Journal of Languages' } \\
\text { Education and Teaching }\end{array}$ & 2 & Diğer endeksler (MLA) & 0,134 \\
\hline $\begin{array}{l}\text { RumeliDE Dil ve } \\
\text { Araştırmaları Dergis }\end{array}$ & 2 & TR Dizin & 0,077 \\
\hline
\end{tabular}

\section{*SOBİAD 2019 Dergi Etki Faktörü}

Türkçe Eğitimi akademik alanındaki araştırmacılar doktora tezlerinden yayın yapmak için 56 farklı dergide makale yayımlamışlardır. Bu durum, alanda tercih edilen dergilerin dağılım olarak 80/20 kuralına uygun olmadığını göstermektedir. 80/20 kuralı, bir alandaki yayınların \%80'inin kaynakların (yayıncıların) \%20'si tarafından üretildiği görüusüne dayanmaktadır (Yılmaz, 2005; Nisonger, 2008). Tezlerden 132'si 56 farklı dergide 
yayımlanmış, 56 derginin \%20'si olan 11 farklı dergide ise toplam 72 yayın yapılmıştır. Bu bulgulara göre alanda çekirdek dergi koleksiyonunun olmadığını söylemek mümkündür.

Yayına dönüşen yayınların dizinlere göre dağılımına bakıldığında, bu yayınların bir kısmı TR Dizin listesinde bulunan ulusal nitelikli hakemli dergilerde yer almış iken bir kısmı uluslararası dizinlerde taranan dergilerde yayımlanmıştır. Sınırlı sayıda araştırmanın SSCI ve ESCI dizinindeki dergilerde yayımlandığı göze çarpmaktadır. Bulgulara göreAna Dili Eğitimi Dergisi alanda en yoğun olarak tercih edilen yayın organıdır. Ana Dili Eğitimi Dergisi, kuram ve uygulama boyutunda Türkçe Eğitimi akademik alanında bilimsel kültürün yerleşmesine ve araştırma kalitesinin geliştirilmesine ortam hazırlayan ilk akademik platformdur. Bu anlamda dergi, Türkçe Eğitimi alanyazının gelişmesine katkı sağlamaktadır. Dergide, Türkçenin eğitimi ve öğretimi ile ilgili Türkçe ve İngilizce makaleler yayımlanmakta ve temel dil becerileri, Yabancılara Türkçe Öğretimi, çocuk edebiyatı konu alanlarına giren özgün makalelere yer verilmektedir. Derginin yayın hayatına başladığı 2013 ve sonrası dönemde, Türkçe Eğitimi alanında üretilen yayınların düzeyi, alandaki araştırmacıların katkıları sonucunda istikrarlı biçimde artmış ve anlamlı bir düzeye ulaşmıştır. Ana Dili Eğitimi Dergisi'nin Türkçe Eğitimi özelinde yayımlanan ilk akademik yayın organı olması ve alanının ulusal kimliği nedenleri ile bilim ekosisteminde araştırmacılar tarafından yoğun olarak tercih edilmesi anlaşılır bir durumdur. Alanyazında yapılan önceki araştırmalar da, derginin alanın gelişme sürecine etkide bulunduğunu ve alandaki bilgi alışverişinin güçlenmesine yardımcı olduğunu göstermektedir (Karagöz ve Koç Ardıç, 2019; Cin Şeker, 2020). Ana Dili Eğitimi Dergisi'nin ardından makalelere sırasıyla Mustafa Kemal Üniversitesi Sosyal Bilimler Enstitüsü Dergisi ve Turkish Studies ev sahipliği yapmıştır. Alan açısından önemli bir işleve sahip olan bu iki yayın organı, alanda bilimsel iletişimi sağlayacak kaynak bir derginin olmadığı ilk yıllarda üretilen bilgilerin paylaşılmasına olanak tanıyarak Türkçe Eğitimi akademik alanının bilimsel ilerlemesine katkıda bulunmuştur.

Bilimsel dergilerin bilimsel performansının önemli göstergelerinden biri de dergi etki faktörüdür (Garfield, 1976). Dergi etki faktörü, bir derginin son bir yılda aldığı toplam atıf sayısının, daha önceki iki yılda yayınlanan makale sayısına bölünmesi ile elde edilir (Ertekin, 2014). Çalışmanın bu bölümünde araştırmacıların, tercih ettikleri yayın organları ile bu yayın organlarının etki faktörleri arasındaki ilişkinin hangi yönde olduğu irdelenmiş ve istatistiksel olarak negatif bir ilişkinin olduğu belirlenmiştir (Spearman's $r=, 059, p=, 849$ ). Bu doğrultuda, araştırmacıların yayın için dergilerin etki faktörü değerlerini dikkate almadıkları görülmektedir. Bununla birlikte araştırmacılar, yayın için etki faktörü yüksek dergileri hedeflemelidirler. Çünkü etki faktörü yüksek dergilerde yayımlanan çalışmalar, görünürlük ve etki katsayısı bakımından önemli bir potansiyele sahiptir.

\section{TARTIŞMA}

Bilimsel araştırma sürecinin önemli çıktılarından biri olan doktora tezleri, bilim alanının gelişimine katkı sağlayacak yeni ve özgün akademik bilgi üretiminde ve üretilen bilginin yayılma sürecinin ortaya konulmasında etkin bir role sahiptir (Nieminen ve diğerleri, 2007; Arriola-Quiroz ve diğerleri, 2010; Ferreras-Fernández ve diğerleri, 2016; Morichika \& Shibayama, 2016). Bu açıdan bakıldığında bilim alanlarını daha iyi anlamaya ve gelecekteki gelişimi için bir temel oluşturmaya katkı sunmaktadır (Zong ve diğerleri, 2013; Ramos-Pardo \& Sánchez-Antolín, 2017; Correia, Paredes \& Fonseca, 2018; Kim, Hansen \& Helps, 2018). Diğer bir deyişle doktora tezleri alandaki bilimsel etkinliği takip etmeye 
yardımcı olmakta ve bilimsel birikime yönelik içgörü sağlamaktadır. Bu doğrultuda günümüze kadar olan dönemde Türkçe Eğitimi alanında tamamlanan doktora tezlerini gözden geçirerek alanın mevcut durumunu betimlemeyi ve gelecekteki tezler için potansiyel araştırma yönlerini ortaya koymayı amaçlayan araştırmada, alanda savunulan tüm tezler içerik analizi tekniğiyle çözümlenmiştir. Çalışmada çeyrek asırlık bir dönemi bütüncül olarak analiz etmek suretiyle alanyazın temelli gelişmeler sunularak alanının genel durumuna ilişkin bilim tabanlı alan farkındalığının oluşturulmasına katkı yapmaya çalışılmıştır. Böylece alanın gelişmesine yönelik çok yönlü ve detaylı analizler yapılabilecek ve bulgulara göre tez hazırlama ve yayın yapma süreçlerine yönelik bir yol haritası çizmek mümkün olabilecektir.

Alanda lisansüstü programların sayısındaki artışa paralel, yıllar içinde tez sayılarında kademeli olarak bir artış gözlenmeye başlamış; 2015 yılında 25 yıllık süreçteki en yüksek sayıya ulaşılmıştır. Bu yıldan sonra YÖK'ün doktora programları için getirdiği yasal düzenlemelerle tez sayıları keskin bir düşüş kaydetmiştir. Buna karşılık 13 devlet üniversitesinde Türkçe Eğitimi doktora programının aktif olarak yürütüldüğü (YÖK, 2020) düşünüldüğünde gelecek yıllarda tez sayılarında bir artış yaşanacağı söylenebilir.

Tezlerin ağırlıklı olarak Prof. Dr. unvanlı öğretim üyelerinin danışmanlığında hazırlandığı belirlenmiştir. Danışman unvanlarına dair bulgular önceki araştırmaların sonuçları ile örtüşmektedir (Altın, 2004; Tavşancıl ve diğerleri, 2010; Al ve Doğan, 2012; Alpaydın ve Erol, 2017; Aydın, 2017). Bu çalışmalarda da lisansüstü tezlerin çoğunlukla Prof. Dr. unvanlı akademisyenlerin denetim ve gözetiminde hazırlandığ Nitekim nitelikli tez ve araştırma üretimini sağlayan temel dinamiklerden biri de tez danışmanının unvanıdır (Iş̧ksoluğu, 1994). Danışmanın akademik unvanı, bilime yaptığı katkının bir göstergesidir. Buna göre akademik yetkinliğini kanıtlamış unvanlı araştırmacıların yönetiminde tamamlanan tezlerin nitelik açısından olumlu bir görünüme işaret ettiği düşünülmektedir.

Araştırmacılar, alan içindeki paradigmalar, eğilimler, yöntemler ve teknikler hakkında bilgi sahibi olarak, kendi araştırmalarını tasarlar ve üretirler (Araújo, 2006; Case, 2007; Kwan, 2010; Harley, 2013; Horta \& Santos, 2016). Bu açıdan bakıldığında bilimsel iletişimde dikkate alınması gereken temel araştırma parametreleri bulunmaktadır. Konusal analiz, yöntemsel eğilimler ve araştırma çıktıları bunlardan bazılarıdır. Doktora tezlerinin konu dağılımı, üç ana zaman diliminin ortaya çıktığını göstermektedir: 1) Dil bilgisi öğretimi, okuma becerisi ve tür öğretimi (1995-2009), 2) Yabancılara Türkçe Öğretimi, yazma becerisi, okuma anlama, çocuk edebiyatı, değerler eğitimi ve dil bilgisi öğretimi (2010-2014), ve 3) Yabancilara Türkçe Öğretimi, okuma becerisi, yazma becerisi (2015-2020). Buna göre tezlerde Yabancılara Türkçe Öğretimi, okuma becerisi ve yazma becerisi yoğun olarak çalışılmıştır. Konuşma ve dinleme becerisinin diğer dil becerileri kadar ilgi görmediğini söylemek mümkündür. Bu bulgular alanyazındaki önceki çalışmaların (Yıldız, 2016; Ceren, Aydın ve Onarıcıoğlu, 2018) sonuçlarıyla örtüşmektedir.

Araştırma bulgularına göre nitel ve nicel yaklaşımları birleştiren karma yöntem, tezlerde en çok benimsenen araştırma modelidir. Bu sonuç üzerinden Türkçe Eğitimi doktora tezlerinin başlangıcından günümüze yaşadığı yöntemsel değişime yönelikdeğerlendirmeler yapılabilir. Buna göre doktor adayları karma desenleri tercih ederek bulguların geçerliliğini artırma, araştırma konusunun kapsamlı resmini ortaya koyma, olguların karmaşık doğasını geniş bir bakış açısıyla betimleme olană̆ı bulmuşlardır 
(Robson, 2015). Bu durum alandaki araştırma altyapısının bir çeşitlilik içinde güçlü bir belleğe ulaştığını göstermektedir. Çalışmanın bu bulgusu, Göçer ve Arslan'ın (2018) bulguları ile benzerlik göstermektedir. Ayrıca araştırma paradigması bağlamındaki gelişimin nicel ve nitel tezlerde de yaşandığı belirlenmiştir. Nicel araştırma yaklaşımının benimsendiği ilk tezlerde doktor adayları, daha çok betimsel araştırma sistematiğini kullanmışlardır. 2010 yılı ile birlikte deneysel desenlere yönelim artmıştır. Yine 2010 yılına kadar üretilen nitel tezlerde araştırmacıların çalışmalarını tek yönlü planladıkları, sonraki tezlerin ise daha detaylı bir biçimde tasarlandıkları anlaşılmıştır.

25 yıllık dönemde Türkçe Eğitimi doktora programları ve akademisyenleri, kuruluş ve gelişme dönemini içeren yapılanma süreci içerisine girmişlerdir. Bu süreçte hem alanın ilk lisansüstü programları açılmış hem de alanda bir öğrenme çevresi oluşmaya başlamıştır. Özellikle akademik yükselmelerde uluslararası yayın yapma koşulunun istenmesi ile birlikte araştırmacılar atıf dizinlerinde yayın yapmaya başlamışlardır. 2016 Nisan ve öncesi Doçentlik başvurusu dönemlerinde SSCI, A\&HCI ya da eğitimle ilgili uluslararası alan indekslerinde (ERIC, Australian Education Index, British Education Index, Education Full Text (H. W. Wilson) tek yazarlı bir makale yayınlamak yeterli iken 2016 yılı Aralık dönemi ile birlikte uluslararası makale yanında lisansüstü tezlerden yayın üretmek koşulu da getirilmiştir. Yüksek Öğretim Kurulunun getirdiği politika değişikliği ile birlikte alandaki araştırmacılar da başvuru koşullarını sağlamak amacıyla gerek ulusal atıf dizininde taranan gerekse uluslararası atıf dizinlerinde indekslenen dergilerde yayın yapmaya yönelmişlerdir. Ayrıca tezden yayın üretimi salt yükselme kriterlerini sağlama aracı olarak da görülmemelidir. Zira doktora tezi, araştırmacının potansiyeli ve tezin akademik niteliği hakkında ayrıntılı ve güncel bilgi içermektedir. Bu nedenle genç araştırmacıların tanınırlık ve görünürlük kazanmaları açısından tezlerini yayına dönüştürerek bilimsel ağın dikkatine sunmaları yararlı olabilir.

Buna karşılık daha önceki dönemlerdeki bulgulara benzer şekilde (Şeref ve Karagöz, 2019b), Türkçe Eğitimi alanında bilimsel yayınlar için saygın atıf dizinlerinde yayın yapma eğilimi sağlanamamıştır. Tezlerden üretilen yayınlar çoğunlukla Türkiye kaynaklı dergilerde ulusal makale formatında yayımlanmıştır. Web of Science (SSCI/ESCI/A\&HCI) atıf dizininde listelenen yayın sayısı oldukça azdır. Uluslararası indeksli dergilerde yayın yapmaya gereken önemin verilmemesi, alan araştırmacılarının dil problemi gibi durumlar bu düşük oranın nedenleri arasında sayılabilir. Aynı zamanda söz konusu bibliyometrik veri tabanında dizinlenen yayınların tamamı Türkiye adresli dergilerde yayımlanmıştır (Tonta, 2017). Bu durum Türkçe Eğitimi alanı ile küresel dil eğitimi alanları arasında yayınlar üzerinden gerçekleşen bilimsel iletişimin niceliğini ve niteliğini olumsuz yönde etkilemektedir. Bu bakımdan alanda tamamlanan doktora tezlerinin öncelikle önemli bir araştırma çıktısı olarak görülmesi gerekmektedir. Bu doğrultuda doktora tezlerinin akademik değeri yüksek araştırmalar olduğu anlayışı benimsenmeli, saygın dizinlerde yayına dönüşmesi özendirilmeli ve desteklenmelidir. Böylece tezlerin uluslararası indeksli dergilerde yayımlanması doktora çalışmalarının kalitesini artırabilir. Bu durum görünmeyen bilimin özgün ürünlerinden olan doktora tezlerinin bilime daha fazla katkıda bulunmasına ortam hazırlayabilir (Suber, 2012). Böylelikle alanda üretilen kaliteli ve etki düzeyi yüksek yayınların bilimsel iletişime ivme kazandıracağı ve Türkiye'nin dünya bilimsel göstergelerindeki konumunu daha yukarı noktalara taşımaya katkı sağlayacağı düşünülmektedir. 


\section{SONUÇ}

Türkçe Eğitimi akademik alanının kuruluşundan bu yana 30 yıl geçmiştir. Türkiye'de, 80'li yılların sonunda başlayan ve öğretmen yetiştirme alanlarında özellikle ilgi gören bir çalışma alanıdır. Bununla birlikte, diğer eğitim bilimleri ve öğretmen yetiştirme alanlarına kıyasla Türkçe Eğitimi alanının araştırma ve uygulama sahası sınırlıdır. Bu bağlamda, genel olarak araştırma alanında ulusal bilim dinamiği egemendir. Bu koşullar çerçevesinde, söz konusu durum alanın küresel dil eğitimi alanyazınına eklemlenme sürecinin yavaş ilerlemesine neden olmaktadır. Esas olarak Türkçe Eğitimi, bir dil eğitimi alanı olduğu için küresel alanyazınla bağlantı kurmaya son derece uygundur. Ancak alandaki doktora tezleri üzerinde böyle bir bakış açısının olduğunu söylemek olanaklı değildir. Kimi tezlerin konu, başlık, yöntem vb. bölümleri açısından yüksek düzeyde benzer olduğu dikkat çekmektedir. $\mathrm{Bu}$ durum çalışmaların özgünlük ve akademik niteliğini sorgulanır hâle getirmektedir. Dolayısıyla üretilen tezler, saygın bilim dergilerinde yayımlanmaya değer kalite ve düzeye erişememektedir. $\mathrm{Bu}$ nedenle genç araştırmacılar, küresel dil eğitimi araştırmalarını incelemek suretiyle özgün tez konuları tespit edebilirler. Çünkü seçkin bilim dergileri, bilimsel gelişim veakademik ilerlemenin odak kaynaklarındanbiridir. Bu doğrultuda etki değeri yüksek Modern Language Journal, Foreign Language Annals, Canadian Modern Language Review, IBERICA, TESOL Quarterly, Language and Education, Language Policy gibi dil eğitimi ve dilbilim dergilerinin takip edilmesi hem alandaki çalışmaların bilime katkısının güçlenmesine hem de alandaki bilim insanlarının küresel bilgi birikiminden etkin biçimde yararlanmasına olanak tanıyabilir. Bu anlayışla hazırlanan tezler ileride bilim çevrelerinde saygı gören dergilerde yayımlanma olanağı bulabilir. Böylelikle Türkçe Eğitimi alanındaki yerellik sorunu aşılarak alana küresel bir araştırma alanı kimliği kazandırılabilir. Bu kapsamda politika yapıcılara, araştırmacılara yönelik olarak şu öneriler getirilebilir:

Uluslararası saygın atıf dizinlerinde yer alan yayın sayısının artırılmasına dönük bilgilendirici ve özendirici çalışmalar yoğunlaştııılmalıdır.

Periyodik olarak benzer bir yaklaşımla alandaki doktora tezlerinin gözden geçirilmesi alanın bilimsel durumunu izlemek açısından yararlı olabilir.

\section{SUMMARY}

One of the scientific studies that play a key role in the development of academic disciplines is Ph.D. dissertations. They provide information about the structure and organization of scientific subjects. In this respect, they provide a useful basis for understanding research trends and the current status of the subject. This study aims to shed light on the research memory and intellectual background of Ph.D. theses submitted on Turkish Language Education and to reveal the impact of these dissertations on scientific development. In this way, it will be possible to present a more detailed perspective on Ph.D. dissertations on the subject through different parameters and to examine the impact of the dissertations on the information exchange among the academic community. This understanding will enable us to identify the similarities and differences in the research topics examined in the dissertations. So, it will be possible to focus on the points that create an information gap on the subject.

This study reviews the Ph.D. dissertations on Turkish Language Education between 1995 and 2020, describing the current state of the subject and revealing potential research topics for future dissertations. The study provides literature-based developments by 
analyzing a quarter-century holistically and creates science-based awareness of the subject. The study also draws a roadmap for dissertation preparation and publication processes thanks to the results achieved for this purpose. So, the study is important to understand the general structure of Ph.D. dissertations on Turkish Language Education and evaluating their publication process, as it reveals the research profile Ph.D. dissertations on Turkish Language Education submitted between 1995-2020 in Turkey. The research questions of the study are:

For Ph. D. dissertations on Turkish Language education submitted between 1995-2020,

a. How are they distributed over the years?

b. How is the title of their supervisors distributed?

c. How are their research themes distributed?

d. How are they distributed according to their research designs?

e. How is their process to turn into a publication?

This study is descriptive research. With a descriptive perspective, it examines the research on Turkish Language Education with a comprehensive understanding through Ph.D. dissertations submitted between 1995 and 2020. The researchers collected the data using a two-stage strategy. First, they searched for Ph.D. dissertations. For this, they used the National Thesis Center by the Council of Higher Education as a data source. Then, they investigated the rate of the publication process of the dissertations. Finally, they analyzed the data using content analysis.

The researchers determined that there are 248 Ph.D. dissertations on Turkish Language education. The first dissertation was submitted in 1995. Dissertation production sped up in 2006 and after, with the of researchers with a Ph. D. degree in Turkish education. The main reason for this increase is the opening of Turkish Education Ph.D. programs in many universities and the interest of junior researchers in academic studies on this subject.

Another important result of the study is the fact that the dissertations were mostly supervised by professor doctors. The mixed-method, which combines qualitative and quantitative approaches, is the most widely adopted model in dissertations. Specifically, most of the dissertations have qualitative tools such as interview or observation after data collection with scales or questionnaires, to check whether the findings support each other.

The most popular research topic on the subject is teaching Turkish to foreigners. Especially Yunus Emre Institute's studies on teaching Turkish and Turkish culture are among the key research topics of the dissertations. The support of institutions such as Yunus Emre Institute and the Turkish Cooperation and Coordination Agency (TIKA) to teaching Turkish contributed to the production of scientific studies.

The researchers concluded that reputable citation indexes are less preferred for scientific publications on Turkish education. Dissertation-based publications were mostly published as national articles in journals in Turkey. Journal of Mother Tongue Education, Mustafa Kemal University Journal of Social Sciences Institute, and Turkish Studies have been the most preferred journals to publish. The Journal of Mother Tongue Education is the main scientific communication channel of Turkish Language education. This journal is a specialized publication on Turkish Language education. The number of publications listed 
on the Web of Science (SSCI/ESCI/A\&HCI) citation index is quite low. Most publications in this index are in Education and Science journal.

It has been 30 years since the establishment of the Turkish Education academic field. In Turkey, it started at the end of the 80s and has become an area of great interest in teacher training. However, compared to other educational sciences and teacher training fields, the field of research and application of Turkish Education is limited. This situation causes the national science dynamic to dominate in this research field. Therefore, including this field in global language education is progressing slowly. As a language education, Turkish Language Education is very suitable for connecting with global literature. However, it is not possible to say that such a point of view exists on Ph.D. dissertations on Turkish Language education. It is noteworthy that some dissertations are highly similar in terms of subject, title, and method. This situation harms the originality and academic quality of the studies. So, the dissertations submitted do not reach the quality and level that is worth publishing in high-quality science journals.

According to this result, it is recommended that supervisors and $\mathrm{Ph}$. D. students follow high-impact language education and linguistics journals such as Modern Language Journal, Foreign Language Annals, Canadian Modern Language Review, IBERICA, TESOL Quarterly, Language and Education, and Language Policy. In this way, the contribution of future studies to science is strengthened and scientists benefit from global information effectively. So, the locality problem in Turkish Language education can be overcome and the field can turn into a global research discipline.

As a result, this study is a scientific example that examines the structure and content of all-time Ph.D. dissertations in Turkish Language education and publication processes of these dissertations. It also serves as a model to apply its analyses to future studies using similar methods.

Makale Bilgileri

\begin{tabular}{ll}
\hline \multirow{2}{*}{ Etik Kurul Kararı: } & Çalışma, Tokat Gaziosmanpaşa Üniversitesinin 10.12.2020 tarihli \\
Katılımcı Rızası: & ve 2020/19,1-12 onay numaralı kararı ile Etik Onay almıştır. \\
Mali Destek: & Çalışma için mali destek alınmamıştır. \\
Çıkar Çatışması: & Çalışmada kişiler ve kurumlar arası çıkar çatışması \\
belif Hakları: & Telif hakkımamaktadır.
\end{tabular}

Article Information

Ethics Committee Approval:

Informed Consent:

Financial Support:

Conflict of Interest:

Copyrights:
The study received Ethical Approval from Tokat Gaziosmanpaşa University with the approval number of 2020/19, 1-12 and the date of10.12.2020.

No participants.

No financial support.

No conflict of interest.

No copyrighted material has been used. 


\section{KAYNAKÇA}

Akaydın, Ş. \& Çeçen M. A. (2015). Okuma becerisiyle ilgili makaleler üzerine bir içerik analizi. Eğitim ve Bilim, 40(178), 183- 198.

Al, U. \& Doğan, G. (2012). Hacettepe Üniversitesi Bilgi ve Belge Yönetimi Bölümü tezlerinin atıf analizi. Türk Kütüphaneciliği, 26(2), 349-369.

Alpaydın, Y.\& Erol, İ. (2017). Türkiye'de eğitim ekonomisi alanında yapılan lisansüstü tezlerin incelenmesi. Marmara Üniversitesi Atatürk Eğitim Fakültesi Eğitim Bilimleri Dergisi, 45(45), 23-41.

Altın, N. (2004). Eğitim programları ve öğretim alanında yapılan yüksek lisans tezlerinin analizi (Ankara, Gazi ve Hacettepe Üniversitesi). Yayınlanmamış Yüksek Lisans Tezi. Ankara Üniversitesi, Ankara.

Andersen, J. P. \& Hammarfelt, B. (2011). Price revisited: on the growth of dissertations in eight research fields. Scientometrics, 88(2), 371-383. doi:10.1007/s11192-011-0408-8.

Araújo, C. A. (2006). Bibliometria: evolução histórica e questões atuais. Em questão, 12(1), 1132.

Arriola-Quiroz, I., Curioso, W. H., Cruz-Encarnacion, M.\& Gayoso, O. (2010). Characteristics and publication patterns of theses from a Peruvian medical school. Health Information $\mathcal{E}$ Libraries Journal, 27(2), 148-154.

Aydın, B. (2017). Yükseköğretim kurulu tez merkezinde (yöktez) yiyecek içecek işletmeciliği alanında kayıtlı bulunan tezlerin bibliyometrik analizi. Disiplinlerarası Akademik Turizm Dergisi, 2(1), 23-38.

Bangani, S. (2018). The impact of electronic theses and dissertations: a study of the institutional repository of a university in South Africa. Scientometrics, 115(1), 131-151.

Bayramlar, H., Karadağ, R., Kanra Gürtürk, A. Y., Öçal, A., Dă̆, Y., \& Sarı, Ü. (2015). Publication patterns of ophthalmology residency dissertations in Turkey. European Journal of General Medicine, 12(3), 213-216.

Boyacı, S. \& Demirkol, S. (2018). Türkçe eğitimi alanında yapılan doktora tezlerinin incelenmesi. Ana Dili Ĕ̆itimi Dergisi, 6(2), 512-531.

Bozkurt, B. Ü. \& Uzun, N. E. (2015). Türkçenin eğitimi-öğretimine ilişkin bir alanyazını değerlendirmesi: uluslararası bilimsel toplantılarda eğilimler/yönelimler, Dil Eğitimi ve Araştırmaları Dergisi, 1/2, 1-15.

Börekçi, M. (2015). Bir bilim alanı olarak Türkçe ve Türkçe Eğitimi. Erzincan Üniversitesi Sosyal Bilimler Enstitüsü Dergisi, II, 405-414.

Broadus, R. N. (1987). Toward a definition of "bibliometrics". Scientometrics, 12(5-6), 373-379.

Büyükikiz, K. (2014). Yabancılara Türkçe öğretimi alanında hazırlanan lisansüstü tezler üzerine bir inceleme. Mustafa Kemal Üniversitesi Sosyal Bilimler Enstitüsü Dergisi, 11(25), 203-213.

Case, D. O. (2007). Looking for information: A survey of research on information seeking, needs, and behavior. 2nd ed. Amsterdam: Elsevier/Academic Press.

Ceren, D., Aydın, M. \& Onarıcıoğlu, A. S. (2018). Okuma eğitimi üzerine yapılan tezlerde eğilimler: Bir içerik analizi çalışması. Ahi Evran Üniversitesi Kırşehir Eğitim Fakültesi Dergisi, 19(3), 2377- 2392 
Cin Şeker, Z. (2020). Ana Dili Eğitimi Dergisi'nde yayınlanan makalelerin anahtar kelimeleri üzerine betimsel bir analiz. Ana Dili Ĕ̆itimi Dergisi, 8(3), 797-811.

Correia, A., Paredes, H., \& Fonseca, B. (2018). Scientometric analysis of scientific publications in CSCW. Scientometrics, 114(1), 31-89.

Coşkun, E., Balcı, A. \& Özçakmak, H. (2013). Trends in writing education: An analysis of postgraduate theses written in Turkey. Procedia-Social and Behavioral Sciences, 93, 15261530.

Creswell, J. W. (2016). Araştırma deseni. (Çev. Ed. S. B. Demir). Ankara: Eğiten Kitap Yayıncilik.

DeMola, P. M., Hill, D. L., Rogers, K., \& Abboud, J. A. (2009). Publication rate of abstracts presented at the shoulder and elbow session of the American Academy of Orthopaedic Surgery. Clinical Orthopaedics and Related Research, 467(6), 1629-1633.

Dhaliwal, U., Singh, N., \& Bhatia, A. (2010). Masters theses from a university medical college: Publication in indexed scientific journals. Indian journal of ophthalmology, 58(2), 101.

Donegan, D. J., Kim, T. W., \& Lee, G. C. (2010). Publication rates of presentations at an annual meeting of the American Academy of Orthopaedic Surgeons. Clinical Orthopaedics and Related Research, 468(5), 1428-1435.

Echeverria, M., Stuart, D., \& Blanke, T. (2015). Medical theses and derivative articles: dissemination of contents and publication patterns. Scientometrics, 102(1), 559-586.

Ertekin, C. (2014). Bilimsel araştırma ve bilimsel performans ölçümü. Türk Nöroloji Dergisi, 20(2), 32-36.

Evans, S. C., Amaro, C. M., Herbert, R., Blossom, J. B., \& Roberts, M. C. (2018). “Are you gonna publish that?" Peer-reviewed publication outcomes of doctoral dissertations in psychology. PloS one,13(2), e0192219.

Eyüp, B. (2020). Türkçe öğretmenleri ile ilgili yapılan lisansüstü tezlerin eğilimleri: Bir içerik analizi (2000-2019). RumeliDE Dil ve Edebiyat Araştırmaları Dergisi, (21), 536-558. DOI: 10.29000/rumelide.843489.

Falkingham, L.T. \& Reeves, R. (1998). Context analysis-a technique for analysing research in a field, applied to literature on the management of R\&D at the section level. Scientometrics, 42(2), 97-120, available at: https://doi.org/10.1007/BF02458351

Fernández-Cano, A., Torralbo, M., \& Vallejo, M. (2012).Time series of scientific growth in Spanish doctoral theses (1848-2009). Scientometrics, 91(1), 15-36.

Ferreras-Fernández, T., García-Peñalvo, F. J., Merlo-Vega, J. A., \& Martín-Rodero, H. (2016). Providing open access to PhD theses: Visibility and citation benefits. Electronic Library and Information Systems, 50(4), 399-416. doi:10.1108/PROG-04-2016-0039

Finlay, C. S., Sugimoto, C. R., Li, D. F., \& Russell, T. G. (2012). LIS dissertation titles and abstracts (1930-2009): where have all the library gone? Library Quarterly, 82(1), $29-46$. doi:10.1086/662945.

Gao, S. J., Yu, W. Z., \& Luo, F. P. (2009). Citation analysis of PhD thesis at Wuhan University, China. Library Collections, Acquisitions, and Technical Services, 33(1), 8-16.

Garfield, E. (1976). Journal citation reports. Current contents. 7-20. http://www. garfield. Library. upenn. edu/essays/v2p 558y. 
Geuna, A. (2015). Global mobility of research scientists: The economics of who goes where and why. Amsterdam: Elsevier

Gould, J. (2016). What's the point of the PhD thesis?.Nature News, 535(7610), 26.

Göçer, A. \& Arslan, S. (2018). Türkiye'de dil bilgisi öğretimi üzerine hazırlanan lisansüstü tezler hakkında bir meta-analiz çalışması. Kırıkkale Üniversitesi Sosyal Bilimler Dergisi, $8(1), 107-122$.

Güzel, A. (2003a). Eğitim fakültelerinde Türkçe öğretmenliği bölümünün kuruluşu ve hedefleri. Türklük Bilimi Araştırmaları, (13), 7.

Güzel, A. (2003b). Türkçenin eğitimi-öğretimi bölümlerinde kurulması gerekli görülen anabilim dalları hakkında yeni projelerimiz. Türkiyat Araştırmaları Dergisi, 13, 13-86.

Hall, L. \& Burns, L. (2009). Identity development and mentoring in doctoral education. Harvard Educational Review, 79(1), 49-70.

Harley, D. (2013). Scholarly communication: cultural contexts, evolving models. Science, 342(6154), 80-82.

Hernández-González, V., De Pano-Rodríguez, A., \& Reverter-Masia, J. (2020). Spanish doctoral theses in physical activity and sports sciences and authors' scientific publications (LUSTRUM 2013-2017). Scientometrics, 122(1), 661-679.

Horta, H.,\& Santos, J. M. (2016). The impact of publishing during PhD studies on career research publication, visibility, and collaborations. Research in Higher Education, 57(1), 28-50.

Işıksoluğu, M. (1994). Tezler ve danışmanlık. Ĕ̆itim ve Bilim, 18(94), 57-66.

Jones, M. (2013, July). Issues in Doctoral Studies-Forty Years of Journal Discussion: Where have we been and where are we going?.In Proceedings of the Informing Science and Information Technology Education Conference (pp. 83-104).Informing Science Institute.

Kan, O.\& Uzun, G. (2016). Türkçe Eğitimi alanındaki yüksek lisans tezlerinin yöntem bölümlerine ilişkin sözbilimsel yapı özellikleri. Mersin Üniversitesi Eğitim Fakültesi Dergisi, 12(1), 331-343.

Kaptan, S. (1998). Bilimsel araştırma ve istatistik teknikleri (11. Baskı). Ankara: Tek Işık Web Ofset

Karagöz, B. \& Koç Ardıç, İ. (2019). Ana Dili Eğitimi Dergisi'nde yayımlanan makalelerin bibliyometrik analizi. Ana Dili Ĕ̆itimi Dergisi, 7(2), 419-435.

Karagöz, B. \& Şeref, İ. (2020). Yazma becerisiyle ilgili makaleler üzerine bir inceleme: Web of Science veri tabanında eğilimler. Ana Dili Eğitimi Dergisi, 8(1), 67-86.

Kim, S., Hansen, D., \& Helps, R. (2018). Computing research in the academy: insights from theses and dissertations. Scientometrics, 114(1), 135-158.

Kot, F. C. \& Hendel, D. D. (2012). Emergence and growth of professional doctorates in the United States, United Kingdom, Canada and Australia: A comparative analysis. Studies in Higher Education, 37(3), 345-364.

Kousha, K. \& Thelwall, M. (2019). Can Google Scholar and Mendeley help to assess the scholarly impacts of dissertations?.Journal of Informetrics, 13(2), 467-484.

Krippendorff, K. (2012). Content analysis; An introduction to its methodology (3rd ed.). Thousand Oaks, CA: Sage.

SEFAD, 2021; (46): 43-68 
Kumar, V. \& Stracke, E. (2007).An analysis of written feedback on a PhD thesis. Teaching in Higher Education, 12(4), 461-470.

Kuruppu, P. U. \& Moore, D. C. (2008). Information use by PhD students in agriculture and biology: A dissertation citation analysis. Libraries and the Academy, 8(4), 387-405.

Kushkowski, J. D., Parsons, K. A.\& Wiese, W. H. (2003). Master's and doctoral thesis citations: analysis and trends of a longitudinal study. Libraries and the Academy, 3(3), 459479, doi:10.1353/ pla.2003.0062

Kwan, B. S. C. (2010). An investigation of instruction in research publishing offered in doctoral programs: The Hong Kong case. Higher Education, 59(1), 55-68.

Larivière, V. (2012).On the shoulders of students? The contribution of $\mathrm{PhD}$ students to the advancement of knowledge. Scientometrics, 90(2), 463-481.

Larivière, V., Zuccala, A. \& Archambault, É. (2008). The declining scientific impact of theses: Implications for electronic thesis and dissertation repositories and graduate studies. Scientometrics, 74(1), 109-121.

Lee, A. (2008). How are doctoral students supervised? Concepts of doctoral research supervision. Studies in Higher Education, 33(3), 267-281.

Lindahl, J., Colliander, C., \& Danell, R. (2020). Early career performance and its correlation with gender and publication output during doctoral education. Scientometrics, 122(1), 309-330.

McCallin, A. \& Nayar, S. (2012). Postgraduate research supervision: A critical review of current practice. Teaching in Higher Education, 17(1), 63-74.

Miles, M. B. \& Huberman, A.M. (1994). Qualitative Data Analysis: An Expanded Sourcebook. (2nd Edition). SAGE Publications.

Moher D, Shamseer L, Clarke M, Ghersi D, Liberati A, Petticrew M, et al. Preferred reporting items for systematic review and meta-analysis protocols (PRISMA-P) statement (2015). Systematic Review. 2015;4(1).

Morichika, N. \& Shibayama, S. (2016). Use of dissertation data in science policy research. Scientometrics, 108(1), 221-241.

Nieminen, P., Sipilä, K., Takkinen, H. M., Renko, M., \& Risteli, L. (2007). Medical theses as part of the scientific training in basic medical and dental education: experiences from Finland. BMC Medical Education, 7(1), 51.

Nisonger, T. E. (2008). The "80/20 rule" and core journals. The Serials Librarian, 55(1-2), 62-84.

Ogunyemi, D., Bazargan, M., Norris, K., Jones-Quaidoo, S., Wolf, K., Edelstein, R. \& Calmes, D. (2005). The development of a mandatory medical thesis in an urban medical school. Teaching and Learning in Medicine, 17(4), 363-369.

Oliveira, L. R. S., Figueiredo, A. A., Choi, M., Ferrarez, C. E. P. F., Bastos, A. N., \& Netto, J. M. B. (2009). The publication rate of abstracts presented at the 2003 urological Brazilian meeting. Clinics, 64(4), 345-349.

Overall, N. C., Deane, K. L., \& Peterson, E. R. (2011). Promoting doctoral students' research self-efficacy: Combining academic guidance with autonomy support. Higher Education Research \& Development, 30(6), 791-805.

Powell, R. R. \& Connaway, L. S. (2004). Basic research methods for librarians (4th ed.) Westport, CT: Libraries Unlimited. 
Ramos-Pardo, F. J. \& Sánchez-Antolín, P. (2017). Production of educational theory doctoral theses in Spain (2001-2015). Scientometrics, 112(3), 1615-1630.

Robson, C. (2015). Bilimsel araştırma yöntemleri. (Çev. Ed. Şakir Çınkır ve Nihan Demirkasımoğlu). Ankara: Anı Yayıncılık.

Serenko, A., Bontis, N., Booker, L., Sadeddin, K. \& Hardie, T. (2010), A scientometric analysis of knowledge management and intellectual capital academic literature (1994-2008). Journal of Knowledge Management, 14(1), 3-23.

Sevim, O. \& İşcan, A. (2012).Türkçenin eğitimi ve öğretimi alanında yapılan yüksek lisans tezlerinde geçen anahtar kelimelere dönük bir içerik analizi. Turkish Studies, 7(1), 18631873.

Sevim, O. \& Özdemir-Erem, N. H. (2012). Türkçe Eğitimi alanındaki yüksek lisans tezlerinin başlıklarına ve özetlerine eleştirel bir bakış. Uluslararası Türkçe Edebiyat Kültür Eğitim Dergisi, 1(3), 174-186.

Sipahi, H., Durusoy, R., Ergin, I. Ş. I. L., Hassoy, H., Davas, A., \& Karababa, A. O. (2012). Publication rates of public health theses in international and national peer-review journals in Turkey. Iranian Journal of Public Health, 41(9), 31.

Soler-Monreal, C., Carbonell-Olivares, M., \& Gil-Salom, L. (2011).A contrastive study of the rhetorical organisation of English and Spanish PhD thesis introductions. English for Specific Purposes, 30(1), 4-17.

Sprague S, Bhandari M, Devereaux PJ, et al. (2003). Barriers to full-text publication following presentation of abstracts at annual orthopaedic meetings. JBJS, 85(1), 158-163.

Stubb, J., Pyhältö, K., \& Lonka, K. (2012).The experienced meaning of working with a PhD thesis. Scandinavian Journal of Educational Research, 56(4), 439-456.

Suber, P. (2012). Open access. Cambridge, MA: MIT Press. Erişim adresi: https://dash.harvard.edu/bitstream/handle/1/10752204/9780262517638_Open_Access.pd $\mathrm{f}$ ? sequ ence $=1 \&$ is Allowed $=\mathrm{y}$

Şeref, İ. \& Karagöz, B. (2019a). A bibliometric profile of literature of Turkish language education teaching: A case study of 9th International Language Education-Teaching Conference. European Journal of Alternative Education Studies, 4(1), 106-124.

Şeref, İ. \& Karagöz, B. (2019b). Türkçe Eğitimi akademik alanına ilişkin bir değerlendirme: Web of Science veri tabanına dayalı bibliyometrik inceleme. Dil Eğitimi ve Araştırmaları Dergisi, 5(2), 213-231.

Şeref, İ. \& Karagöz, B. (2020). Citation analysis of graduate theses on teaching of Turkish as a foreign language (1988-2019). Çukurova Üniversitesi Eğitim Fakültesi Dergisi, 49(2), 11451183.

Tavşancıl, E., Çokluk, Ö., Çıtak, G. G., Kezer, F., Yıldırım, Ö. Y. ve Bilican, S. (2010). Eğitim bilimleri enstitülerinde tamamlanmış lisansüstü tezlerin incelenmesi (2000-2008). Ankara Üniversitesi Bilimsel Araştırma Projesi Kesin Raporu.

Tok, M.\& Potur, Ö. (2015). Trends of the academic studies in writing education area (20102014 years). Journal of Mother Tongue Education, 3(4), 1-25.

Tonta, Y. (2017). TÜBİTAK Türkiye Adresli Uluslararası Bilimsel Yayınları Teşvik (UBYT) Programının değerlendirilmesi. Ankara: TÜBITAK ULAKBİM. Retrieved November 18, 2020, from http://ulakbim.tubitak.gov.tr/sites/images/Ulakbim/tonta_ubyt.pdf. 
Trafford, V.,\& Leshem, S. (2008). Stepping stones to achieving your doctorate: By focusing on your viva from the start: Focusing on your viva from the start. McGraw-Hill Education (UK).

Vaismoradi, M., Turunen, H., \& Bondas, T. (2013). Content analysis and thematic analysis: Implications for conducting a qualitative descriptive study. Nursing $\mathcal{E}$ Health Sciences, 15(3), 398-405.

Veletsianos, G.,\& Shepherdson, P. (2016). A systematic analysis and synthesis of the empirical MOOC literature published in 2013-2015. International Review of Research in Open and Distributed Learning, 17(2), 198-221.

Yaman, H.,\& Atay, E. (2007). PhD theses in Turkish sports sciences: A study covering the years 1988-2002. Scientometrics, 71(3), 415-421.

Yazıcı, N. (2013). Çocuk edebiyatı alanında üniversitelerde yapılan lisans sonrası çalışmalar. Hacettepe Üniversitesi Eğitim Fakültesi Dergisi, 28(28-1), 441-452.

Yıldız, D. (2016). Uluslararası dil dergilerinde yayımlanan makalelerin amaç/konu ve yöntem açısından incelenmesi, GEFAD/GUJGEF, 36(2): 399-425.

Yılmaz, M. (2005). 80/20 kuralı. Türk Kütüphaneciliği, 19(3) 308-320.

YÖK. (2020). YÖK Ulusal Tez Merkezi:'Türkçe Eğitimi'. Retrieved October 27, 2020, from https://tez.yok.gov.tr/UlusalTezMerkezi/tezSorguSonucYeni.jsp

Yurtsever, E. \& Gülgöz, S. (1999). The increase in the rate of publications originating from Turkey. Scientometrics, 46(2), 321-336.

Yücel-Toy, B. (2015). Türkiye'deki hizmet öncesi öğretmen eğitimi araştırmalarının tematik analizi ve öğretmen eğitimi politikalarının yansımaları. Ĕ̆itim ve Bilim, 40(178).

Yüksel, M., İpekçi, T., \& Tunçkıran, A. (2018). Publication rates of dissertations written in medical faculties of Turkey in the field of urology between the years 2008, and 2011, and citation analysis: A cross-sectional study. Turkish Journal of Urology, 44(4), 341.

Zainuddin, Z. \& Halili, S. H. (2016). Flipped classroom research and trends from different fields of study. International Review of Research in Open and Distributed Learning, 17(3), 313-340.

Zong, Q. J., Shen, H. Z., Yuan, Q. J., Hu, X. W., Hou, Z. P., \& Deng, S. G. (2013). Doctoral dissertations of Library and Information Science in China: A co-word analysis. Scientometrics, 94(2), 781-799.

http://apps.webofknowledge.com/

https://atif.sobiad.com/index.jsp?modul=impact-faktoru

https://eric.ed.gov/

https://trdizin.gov.tr/

https://yuzikibinbursu.yok.gov.tr/doktora-istatistikleri

https://akademik.yok.gov.tr/AkademikArama/view/searchResultviewListAuthorAndScField s.jsp\#. 